\title{
Who Works for Whom? \\ Worker Sorting in a Model of Entrepreneurship with Heterogeneous Labor Markets*
}

\author{
Emin M. Dinlersoz Henry R. Hyatt Hubert P. Janicki \\ Center for Economic Studies \\ U.S. Census Bureau
}

January 2015

\begin{abstract}
Compared with mature firms, young firms, most of which represent entrepreneurial activity, disproportionately hire younger, nonemployed individuals, and provide them with lower earnings. Furthermore, in recent years the number of young firms has been declining, along with their employment share, employee size, and worker earnings. To account for these facts, this paper introduces heterogeneous labor markets with search frictions to a dynamic model of entrepreneurship. Individuals differ in productivity and wealth. They can choose not to work, become entrepreneurs, or work in one of two sectors: a corporate versus an entrepreneurial sector. The differences in production technology and labor market frictions across the sectors lead to sector-specific wages. Worker sorting across sectors arises, as individuals with lower assets and higher productivity tend to take lower-paying jobs in the entrepreneurial sector because they do not have enough savings to smooth consumption while unemployed until the arrival of a higher-paying corporate sector job offer. This sorting is found to be consistent with the data on the average net worth of workers in young versus mature firms. The model is also used to explore potential mechanisms behind the recent decline in entrepreneurship in the U.S.
\end{abstract}

*Any opinions and conclusions expressed herein are those of the authors and do not necessarily represent the views of the U.S. Census Bureau. All results have been reviewed to ensure that no confidential data are disclosed. Contact information: Center for Economic Studies, U.S. Census Bureau, 4600 Silver Hill Road, Suitland, MD 20746. E-mails: emin.m.dinlersoz@census.gov, henry.r.hyatt@census.gov, hubert.p.janicki@census.gov . 


\section{Introduction}

Many entrepreneurs are job creators, but the jobs they create may not always be the most desirable ones. A variety of new data sources for the U.S. have confirmed that young firms, most of which represent entrepreneurial activity, provide lower worker earnings on average than mature firms and tend to hire more from the pool of workers who are nonemployed. While young firms create a disproportionate share of new jobs, such jobs also disappear at a high rate. The new data sources also reveal some major changes in the entrepreneurial sector of the U.S. economy in the past couple of decades. The number of young employer businesses has been stagnant, and even started to fall recently. The share of employment in young firms has been shrinking. The average real earnings of workers in young firms have also declined over time, both in absolute terms and relative to mature firms. Young firms have also been operating at an increasingly smaller average scale, as measured by employment.

Despite the well-recognized contribution of young firms to job creation and dynamism of the U.S. economy, the mechanisms by which workers sort themselves across young versus mature firms remain relatively less understood. What kind of workers choose to work for young versus mature firms and why? How is this sorting of workers related to the wage gap between these two groups of firms? These questions demand a framework where wages and worker characteristics for the two types of firms are jointly determined. Furthermore, the causes and consequences of the decline in the entrepreneurial sector have not yet been analyzed in depth. In particular, it is not known how much the differences in worker characteristics, production technologies, and financial and labor market frictions for young versus mature firms may contribute to the recent trends. A better understanding of the functioning of the labor markets for young versus mature firms is a prerequisite for the analysis of how the two group of firms fare under changing conditions for the U.S. economy in recent decades.

This paper develops a dynamic model of entrepreneurship towards an analysis of the recent evolution of the entrepreneurial sector in the U.S. In the model, individuals vary in their wealth and ability (or productivity), both as a worker and an entrepreneur. Worker and entrepreneurial ability both change over time. Every period, individuals make choices regarding work, consumption, and savings. Each individual can choose to not work, be an entrepreneur, or work as an employee in one of the two sectors, entrepreneurial or corporate, which represent the population of young and mature firms, respectively. The entrepreneurial production is subject to diminishing returns that arise from the limits to entrepreneurs' span-of-control, whereas corporations can scale up production without such restrictions. There are two types of frictions. First, entrepreneurs face financial constraints. They can borrow only up to a limit to operate their businesses. Second, the matching of workers to firms is subject to frictions in the labor 
market. Not all nonemployed individuals can find a job, and workers can be separated from their employers involuntarily. The labor market frictions vary across the entrepreneurial and corporate sectors: job offers come at different rates from the two sectors. Furthermore, in a given period each individual can get a job offer only from one of these sectors. As a result, there are distinct labor markets for the two sectors at any point in time. However, workers can flow in and out of these two markets over time subject to the frictions. In this sense, the two labor markets are intertemporally connected. The differences in production technologies across the two sectors and the labor market frictions together lead to different sectoral wages per unit of worker efficiency, which facilitate sorting of workers across the sectors.

The model is related to recent models of entrepreneurship studied by Quadrini (2000), Cagetti and De Nardi (2004), Kitao (2008), Buera and Shin (2011), and Bassetto, Cagetti, and De Nardi (2013). A common theme in these models is that entrepreneurs accumulate assets at a much higher rate than those who work and those who are nonemployed. Because of this process of asset accumulation, entrepreneurs who have been in business longer operate their businesses at levels close to or at their efficient levels. These models also generate plausible fractions of entrepreneurs in the population, as well as the distributions of wealth for entrepreneurs versus workers. The model considered here shares all of these features. What distinguishes the framework here, however, is the introduction of sector-specific labor market frictions, as in Lucas and Prescott (1974). This innovation can generate employment shares and average earnings in the entrepreneurial and corporate sectors that are consistent with what is observed in the data for young versus mature firms. It also allows an analysis of how the two sectors differ in the type of workers they attract. In addition, the heterogeneity in labor markets implies that employment and earnings in the two sectors give differential responses to changes in the fundamental parameters of the model. Therefore, the model provides an environment for exploring the potential mechanisms behind the recent decline in the entrepreneurial sector in the U.S.

The calibrated model's equilibrium offers a number of insights to the functioning of the entrepreneurial sector. First, the model generates lower average worker earnings and a lower wage per unit of worker efficiency in the entrepreneurial sector relative to the corporate sector. The corporate sector premium in worker earnings is consistent with the firm age-worker earnings premium, an empirical regularity documented by Brown and Medoff (2003), and more recently, by Haltiwanger, Hyatt, McEntarfer, Sousa (2012), Dinlersoz, Hyatt, and Nguyen (2013), and Ouimet and Zarutskie (2014). In the model, the premium emerges due to a combination of factors. One factor is that job offers arrive at different rates from the two sectors. As a result, the wages per unit of worker efficiency are not necessarily equalized across the two sectors. Other factors are the decreasing returns to scale and borrowing constraints in the entrepreneurial sector. These features of the model together imply that entrepreneurs on average operate at lower scales 
and profits than the corporate sector, and can not afford to pay high wages.

Second, the model provides an answer to the fundamental question of who works for whom. It offers an explanation for why less wealthy and more productive individuals may work for young firms. In the calibrated model's equilibrium, the entrepreneurial sector offers lower wage per efficiency unit compared to the corporate sector, owing to the differences in production technologies and labor market frictions. If a nonemployed individual receives an offer from the entrepreneurial sector, the worker has to decide whether to reject this offer and wait for an offer from the higher-paying corporate sector. Individuals with lower levels of savings and higher productivity tend to accept job offers from the entrepreneurial sector rather than waiting. In this sense, the model generates a sorting of individuals by their wealth and ability into the two sectors. This sorting occurs in the absence of any inherent preference for working for startups, or any other compensation entrepreneurial firms can provide their workers to make up for lower worker earnings, such as profit sharing or stock options.

Third, the model provides several empirical predictions that have not been tested in detail. One key prediction, that young firms employ workers with lower assets compared to mature firms, is broadly consistent with the empirical facts about life-cycle asset accumulation, but has yet to be characterized in data. This prediction on the nature of worker sorting is tested using available data on workers' net worth, merged with the data that captures employer characteristics for those workers. The findings from this exercise broadly support the baseline model's prediction that workers in mature firms on average possess higher assets than workers in young firms. In particular, in the baseline model workers in the corporate sector have, on average, about 2.7 times the asset holdings of workers in young firms. The corresponding ratio in the data varies between 1.1 and 2.2 for the period 2001-2011. Another prediction, that workers in the entrepreneurial sector tend to be more productive (have more efficiency units) on average than their counterparts in the corporate sector, has also not been tested in detail. In addition, one aspect of working for entrepreneurs, that lower average worker earnings they provide induce mainly workers with lower levels of assets to accept jobs from them, has implications on the job offer rates from the two sectors. In order to match the empirical moments of interest, the model requires an offer arrival rate from the entrepreneurial sector that is not much lower than that from the corporate sector. ${ }^{1}$ One can infer from this relatively high offer arrival rate from the entrepreneurial sector that it must not be too difficult for entrepreneurs to find workers. For instance, entrepreneurs

\footnotetext{
${ }^{1}$ This difference in the offer arrival rates is consistent with recent work on how firms hire workers. Davis, Faberman, and Haltiwanger (2013) show that the "vacancy yield", that is, the number of workers hired per vacancy, is much higher for small firms than large firms. This finding suggests that firms of different sizes might employ different technologies to find potential workers. Although size is an imperfect proxy for age (most young firms are small, but many small firms are not young), this pattern is consistent with entrepreneurs relying less on formal vacancy postings to obtain workers.
} 
may rely more on personal networks to build their workforce, rather than more costly means of search and screening used by corporations.

Fourth, the model provides a rich framework to explore potential mechanisms behind the recent decline in entrepreneurship. Several performance metrics for the entrepreneurial sector point to a decline in entrepreneurship in the U.S. The number of new employer businesses has been falling in recent years, as documented by Decker, Haltiwanger, Jarmin, and Miranda (2014a). Moreover, Sedlacek, and Sterk (2014) find that the new businesses that do form recently tend to create fewer jobs. Since the 2001 recession, the average worker earnings in young firms have also decreased, relative to mature businesses (see Haltiwanger, Hyatt, McEntarfer, and Sousa (2012)). There is a clear "aging" of U.S. businesses, as the population of young firms shrinks and workers tend to be increasingly employed in mature firms rather than in young ones, as Hathaway and Litan (2014a) document. The decline in the number of startups also explains part of the decline in employment reallocation rates (see Hyatt and Spletzer (2013), Davis and Haltiwanger (2014), and Decker, Haltiwanger, Jarmin, and Miranda (2014b)). The model allows for the exploration of some of the potential reasons behind these trends through a series of experiments, where key parameters of the model are altered one at a time to compare the resulting equilibrium with the baseline.

One candidate explanation for the decline in entrepreneurship is a change in labor market frictions. Lower worker turnover and a lower pace of job-to-job mobility of individuals, particularly for younger workers, have accompanied the decline in entrepreneurship. ${ }^{2}$ Both of these trends may be driven by fundamental shifts in labor market frictions in the form of costs of search, hiring, and separations. For instance, advances in information and recruiting technologies may have altered these costs in a way to favor corporations over entrepreneurial firms. Similarly, some changes in regulations and institutional factors may also have effects on hiring and worker reallocation across all firms. To the extent these considerations increase frictions in the labor market for the entrepreneurial firms compared with that for the mature firms, young firms' ability to match with the type of workers who may be best fits for them can be inhibited. It turns out, however, that in the model the trends in entrepreneurship is not straightforward to explain by an increase in search frictions for the entrepreneurial sector relative to the corporate sector. When search frictions increase in the entrepreneurial sector in the form of a lower job offer rate from this sector, workers tend to leave this sector as it is easier to find jobs in the corporate sector. At the same time, however, the wage per efficiency unit in the entrepreneurial sector also increases and gets closer to the one in the corporate sector, as entrepreneurs now need to offer higher wages to attract workers. In addition, only relatively more productive individuals now prefer to work for the entrepreneurial sector, leading to higher average worker earnings in

\footnotetext{
${ }^{2}$ See, e.g., Decker, Haltiwanger, Jarmin, and Miranda (2014a), p. 19-22.
} 
the entrepreneurial sector. Thus, while a change in search frictions can qualitatively account for the decline in the employment share of young firms, the increase in worker earnings in the entrepreneurial sector is at odds with the decline in the worker earnings in young firms.

It is easier to account for all the trends at once by an increase in financial frictions, represented by a tighter borrowing constraint for entrepreneurs. When entrepreneurs face more restrictions in obtaining financing for their businesses, the model generates qualitatively the observed declines in the number, employment share, average employee size, and average worker earnings of young firms. This experiment may be especially relevant for understanding the impact on young firms of a tighter credit environment that emerged in the aftermath of the Great Recession. ${ }^{3}$ Other experiments show that the observed trends can also be mimiced qualitatively if the average quality of entrepreneurs declines, or when the efficient scale of an entrepreneurial firm is lower. The average quality of entrepreneurs may decline if, for instance, the supply of able entrepreneurs is increasingly limited. ${ }^{4}$ Similarly, increasing regulations and costs of doing business may result in an environment where business expansion is more difficult, leading to entrepreneurial firms of smaller scale on average. Overall, the analysis suggests that increasing financial frictions may be an important factor behind the observed decline in the entrepreneurial sector, but other factors explored may also be working alongside this factor in varying degrees.

The model abstracts from many other aspects of reality that certainly contribute to the observed facts about young versus mature firms. There is no on-the-job search, although there is a job ladder from the low-wage entrepreneurial sector to the high-wage corporate sector in the sense that once a worker in the entrepreneurial sector has accumulated enough assets, the worker will tend to quit to nonemployment and wait for an offer from the corporate sector. Furthermore, individuals are not allowed to choose to work for old entrepreneurs who may have operated entrepreneurial businesses for a long time and accumulated a lot of assets, versus new entrepreneurs who have not. While this distinction may be important, firm age is not a readily available characteristic about individuals that run employer businesses, so there are no empirical moments to match on this front. There is also no notion of age for firms and workers in the model. A more realistic approach would involve gradually aging firms and workers. Adding these features to the model would certainly improve its fit in many dimensions. However, it is not clear whether the results will change qualitatively.

The rest of the paper is organized as follows. The next section documents some stylized facts

\footnotetext{
${ }^{3}$ Recent work has focused on understanding the effects of such an environment on firms and individuals. See, e.g., Haltenhof, Lee, and Stebunovs (2014a,b) and Decker (2014).

${ }^{4}$ For example, Hathaway and Litan (2014b) argue that immigration policy may have played a role in the decline of entrepreneurship by potentially limiting the pool of skilled immigrants who are more likely to become entrepreneurs. In addition, the rising costs of education and human capital accumulation can also lead to the same adverse effect on the supply of able entrepreneurs.
} 
about young and mature firms. Section 3 introduces the model, followed by its calibration in Section 4. The properties of the baseline model are discussed in Section 5. Section 6 offers some empirical evidence on key predictions of the model on worker sorting. Section 7 contains the experiments that explore potential mechanisms behind the decline in entrepreneurship. Section 8 concludes.

\section{Facts about Young versus Mature Firms}

There are some key differences between young and mature firms with respect to the types and earnings of the workers they employ, where these workers are hired from, and where they leave in the event of a separation. These two groups of firms also differ in the shares of employment and firms they account for, and their average scale of operation. Furthermore, the trends in nearly all of these measures have been divergent across the two groups in recent years. The empirical patterns documented in this section motivate the model and its analysis that follow. For the purposes of the empirical analysis, a young firm is defined as one that is at most 5 years old, whereas a mature firm is older than 5 years. While alternative definitions of young versus mature firms can be used, the findings below are robust to the choice of the cutoff. ${ }^{5}$ Only the employer firms are studied, and non-employer businesses are not considered.

It is well-known that young and mature firms in general differ substantially in terms of survival, growth, and employment dynamics. Young firms have much higher exit rates, but surviving young firms exhibit higher net employment growth rates than mature firms. ${ }^{6}$ In addition, both job creation and destruction tend to be higher for young firms. Firm startups (new firms) tend to create jobs disproportionately compared to their share of employment. While startups account only around $3 \%$ of total employment, they account for almost $20 \%$ of gross job creation, even though about $40 \%$ of the jobs created by startups disappear within five years after entry as a result of firm failure. ${ }^{7}$ These patterns suggest that the entrepreneurial sector represented by young firms is a highly turbulent segment of the economy, very different from the population of mature firms. Next, the key characteristics of these two types of firms that are particularly relevant for the model and its analysis are documented.

\footnotetext{
${ }^{5}$ For instance, Haltiwanger, Jarmin and Miranda (2013) use a cutoff of 10 years for young firms. The focus in this paper is more on the entrepreneurial sector, so a lower cutoff seems more appropriate.

${ }^{6}$ See Figures 5 and 7 in Haltiwanger, Jarmin and Miranda (2013). Dunne, Roberts and Samuelson (1990) also provide statistics on establishment (as opposed to firm) exit and growth by age categories that lead to similar regularities.

${ }^{7}$ See, again, Haltiwanger, Jarmin and Miranda (2013).
} 


\subsection{Worker Earnings}

The firm-age premium in worker earnings is an empirical regularity. Brown and Medoff (2003) found that average worker earnings are lower in younger firms. This finding has repeatedly emerged in studies using different datasets. For instance, Kölling, Schabel and Wagner (2002) largely confirm Brown and Medoff's (2003) findings using data that links establishments to workers in Germany, and Heyman (2007) also finds a similar pattern in Swedish data. More recently, Dinlersoz, Hyatt, and Nguyen (2013) provide evidence that new manufacturing establishments in the U.S. provide lower average earnings to their workers than older ones. Ouimet and Zarutskie (2014) also observe a similar gap in average earnings in the matched employer-employee data for the U.S. ${ }^{8}$

How has the firm age premium in earnings evolved in recent years? Figure 1 shows the trends in average monthly earnings for workers in young versus mature firms, using data from the US Census Bureau's Quarterly Workforce Indicators (QWI). ${ }^{9,10}$ Around the mid-1990s, workers in young firms earn about $\$ 2,500$ per month, while the corresponding figure for mature firms is $\$ 3,300 .{ }^{11}$ Worker earnings then rise for both types of firms, but more quickly for young firms, and the gap between the young and the mature reaches a minimum around 2000. The gap then widens again starting with the 2001 recession and continuing through the Great Recession. During the post-2000 period, mature firms experience modest increases in average worker earnings which reach to about $\$ 4,200$ by the end of the time series. In contrast, average earnings in young firms decline to around $\$ 2,800$. Overall, Figure 1 makes clear that young firms offer lower earnings to their workers on average, compared to mature firms. Furthermore, earnings in young firms drift lower within the last decade, both in real terms and relative to mature firms.

\subsection{Employment Share}

Recent work suggests that the employment share of young firms has also been declining. In the annual data from US Census Bureau's Business Dynamics Statistics (BDS), a small decline can be seen comparing the mid-1980s with the mid-1990s. The decline accelerates especially after the 2001 recession, reaching a low in the immediate aftermath of the Great Recession. In addition, the share of jobs created by young firms has also been declining (see, e.g., Haltiwanger,

\footnotetext{
${ }^{8}$ Ouimet and Zarutskie (2014) proxy for firm age using the age associated with a federal tax identifier.

${ }^{9}$ The data pertain to six states that consistently have data from 1993Q1 to 2012Q2. These six states are CA, ID, MD, OR, WA, WI. Quarterly Workforce Indicators data were downloaded from the U.S. Census Bureau's website using the LED data extraction tool.

${ }^{10}$ Similar results were also found by Haltiwanger, Hyatt, McEntarfer, Sousa (2012), who used a larger number of states for a different time period, and reported results for different age groupings.

${ }^{11}$ All figures are in 2009 dollars and the series are seasonally adjusted.
} 
Hyatt, McEntarfer, and Sousa (2012) and Decker, Haltiwanger, Jarmin, and Miranda (2014a)).

How much of the total U.S. employment do young firms account for? Figure 2 shows the share of employment in young firms based on the quarterly observations from the US Census Bureau's Longitudinal Employer-Household Dynamics (LEHD) data. The share stands at around 15\% around 1993, and then trends downward to around $14 \%$ in 1997. It then increases until about 2001, reaching a series high of $16 \%$. After that point, the share falls and reaches a series low of $12 \%$ around 2011. ${ }^{12}$ Figure 2 suggests that the contribution of the entrepreneurial sector to the overall employment in the U.S. has been diminishing.

\subsection{Firm Counts}

The firm counts in young versus mature categories have also evolved differently over the last three decades. Based again on the BDS, Figure 3 shows the number of young and mature firms in the U.S. from 1983 to 2012. While the number of mature firms increases steadily since 1983, the number of young firms has been relatively stagnant around 2 million. There is, however, a clear dip starting with the onset of the Great Recession that reduces the count by about $25 \%$ to 1.5 million in 2012. In contrast, over the sample period the number of mature firms surge by $50 \%$, from 2 million to 3 million. As a result, the share of young firms in the U.S. employer population has been shrinking, from nearly $50 \%$ in 1983 to about $33 \%$ in 2012 . These trends imply that the "density" of young firms (the number of young firms per capita) has also declined over the last thirty years. The number of firms in the entrepreneurial sector has not kept up with the U.S. population.

\subsection{Firm Size}

The average scale of young firms measured by employment has also been shrinking in recent years. The evolution of the average employment of young firms is shown in Figure 4, based on the data from the BDS. Over the sample period, the average size of young firms exhibits some fluctuation within a band of 7.5 to 9 employees. However, the estimated linear trend shown in Figure 4 points to a statistically significant long-term decline. The most recent decline episode starts around the 2001 recession and continues till 2009, after which some recovery is observed. In contrast, the average size of mature firms, shown in Figure 5, does not exhibit any clear long-run trend. The average size for mature firms also fluctuates somewhat over time, and its post-2000 decline resembles the decline in the average size of young firms. However, the post-2000 decline in the average size of young firms is more pronounced, as shown in Figure 6, which pictures the average size of young firms relative to that of mature firms. Over the broader horizon, the average

\footnotetext{
${ }^{12}$ There is also a large jump in 2007 , which is likely a data issue.
} 
size of young firms hovers around one-quarter of the average size of mature firms. The relative size of young firms exhibits a statistically significant decline in the long-run, as the estimated linear trend in Figure 6 suggests. The average size of young firms also shrinks faster than that of mature firms in the post-2000 period.

\subsection{Hires and Separations}

Young and mature firms also exhibit marked differences in their worker hiring and separation patterns. The former tend to have higher hiring and separation rates, and rely more on those individuals without jobs for hiring. ${ }^{13}$ Based on the LEHD data, Figure 7 shows young firms' share of hires from nonemployment and separations to nonemployment. ${ }^{14}$ Between 1998 and 2012, young firms account for, on average, about $25 \%$ of all hires from nonemployment, and about $22 \%$ of separations to nonemployment. Young firms also disproportionately draw their workforce from nonemployment and lose their workers disproportionately to nonemployment. Define the relative hires from nonemployment for young firms as

$$
R_{H}=\frac{\text { (Young firms' share of total hires from nonemployment/Young firms' share of total hires) }}{\text { (Mature firms' share of total hires from nonemployment/Mature firms' share of total hires) }}
$$

The relative separations, $R_{S}$, can be defined analogous to $R_{H}$. If $R_{H}, R_{S}>1$, young firms have a disproportionate share of hires from, and separations to, nonemployment. As shown in Figure $8, R_{H}$ and $R_{S}$ exceed one throughout the sample period. Compared with mature firms, young firms tend to hire more from nonemployment versus from other firms (poaching). In addition, for most of the sample period young firms lose their workers more to nonemployment than to other firms, compared with mature firms. Note also that both $R_{H}$ and $R_{S}$ exhibit important changes over time. They both increase during the years leading to the Great Recession, then fall sharply as the Great Recession progresses after 2007, and start to recover around 2010. The worker flow patterns documented suggest that the labor markets for young versus mature firms function differently. Young firms' shares of hires and separations, and the origins and destinations of worker flows in these firms, hint at potentially distinct labor market frictions for workers in young firms.

\footnotetext{
${ }^{13}$ See Haltiwanger, Hyatt, and McEntarfer (2014) and Hyatt, McEntarfer, McKinney, Tibbets, and Walton (2014).

${ }^{14}$ Identification of worker-level movements by firm age is unique to the LEHD data, and was incorporated as part of the job-to-job flows project, and the data used are those described in Hyatt, McEntarfer, McKinney, Tibbets, and Walton (2014).
} 


\subsection{Summary}

While every mature firm was once young and a firm's transition from youth to maturity is a continuous process of selection and growth, the populations of young and mature firms nevertheless behave like two highly distinct sectors of the economy in many key dimensions. Previous literature has established that firm dynamics exhibit marked differences across the two groups. Young firms are more likely to fail, and tend to grow fast if they survive, whereas failure and growth rates are much lower for mature firms. Young firms also create a disproportionate share of new jobs, even though the jobs they create are also destroyed at a high rate later on. Recent findings in the literature and the additional observations presented here together highlight how workers sort across these two groups of firms. Young firms tend to hire younger workers and those who come disproportionately from the ranks of nonemployed, and provide them with lower earnings.

The findings also paint a somewhat gloomy picture of the entrepreneurial sector of the economy, which predominantly consists of young and small firms. Over the last couple of decades, the number of young firms has been stagnant, and even declined in recent years. Furthermore, they have been accounting for a lower share of the total employment, and their average pay and employee size have also been shrinking recently, both in absolute terms and relative to mature firms.

The main goal of the model in the next section is to provide a framework to account for the observed differences in worker characteristics, employment shares, and average worker earnings across young and mature firms summarized in this section. By doing so, the model seeks to answer the question of who works for whom. A further goal is to use the model's framework to explore potential mechanisms behind the decline in the entrepreneurial sector.

\section{The Model}

The model's structure is motivated by the observations documented in the previous section. First, considering the stark differences between young and mature firms, the model features an economy with two sectors, one entrepreneurial and the other corporate, representing the population of young and mature firms, respectively. These two sectors differ both in production technologies and labor market frictions, which in equilibrium lead to different sectoral wages per efficiency unit of worker and average worker earnings. Second, the model recognizes individuals' heterogeneity in wealth and ability, both as workers and entrepreneurs. This heterogeneity, together with the different wages per efficiency unit and frictions in the sectoral labor markets, generates worker sorting across the two sectors in equilibrium. 
The model extends the framework of incomplete markets with occupational choice in the spirit of Quadrini (2000) to include heterogeneous labor markets as in the "islands" economy of Lucas and Prescott (1974). ${ }^{15}$ There is a unit mass of infinitely-lived agents. Time, $t$, is discrete and all agents share the discount factor, $\beta \in(0,1)$. Each period an agent is endowed with one unit of time, which can be used for production as a worker or an entrepreneur, or for leisure. Agents have identical preferences over consumption and leisure represented by the period utility

$$
u\left(c_{t}, h_{t}\right)=\ln c_{t}-\alpha h_{t},
$$

where $c_{t} \geq 0$ is the consumption, $\alpha>0$ is the disutility from labor, and $h_{t} \in\{0,1\}$ is an indicator of participation in the labor market. If the agent is a worker or an entrepreneur, then $h_{t}=1$; otherwise, $h_{t}=0$.

Each agent possesses an amount, $a_{t} \geq 0$, of assets. Agents differ in their ability (or productivity), both as a worker and an entrepreneur. Worker productivity is summarized by $z_{t}>0-$ the efficiency units of labor an agent can supply in a period. The productivity, $z_{t}$, evolves over time independently across individuals. For each individual, $z_{t}$ follows the process

$$
\begin{aligned}
\ln z_{t} & =\rho_{z} \ln z_{t-1}+\epsilon_{t}^{z}, \\
\epsilon_{t}^{z} & \sim N\left(0, \sigma_{z}\right) .
\end{aligned}
$$

Similar to the worker ability, the entrepreneurial ability, $\theta_{t}$, also evolves independently across individuals according to

$$
\begin{aligned}
\ln \theta_{t} & =\left(1-\rho_{\theta}\right) \mu+\rho_{\theta} \ln \theta_{t-1}+\epsilon_{t}^{\theta}, \\
\epsilon_{t}^{\theta} & \sim N\left(0, \sigma_{\theta}\right) .
\end{aligned}
$$

There are two sectors of production: a corporate and an entrepreneurial sector, denoted by $j \in\{e, f\}$, respectively. Production technologies differ across the two sectors. There is a representative firm in the corporate sector. It generates output, $Y_{t}$, by combining capital, $K_{t}$, and efficiency units of labor, $L_{t}$, by way of a constant-returns-to-scale production technology

$$
Y_{t}=A K_{t}^{\nu} L_{t}^{1-\nu},
$$

where $\nu \in(0,1)$, and $A>0$ is the corporate sector's total factor productivity.

Each firm in the entrepreneurial sector is run by an entrepreneur with ability $\theta_{t}$, who uses capital, $k_{t}$, and efficiency units of labor, $l_{t}$, to produce output, $y_{t}$, via a decreasing-returns-to-scale technology

$$
y_{t}=\theta_{t}\left(k_{t}^{\nu} l_{t}^{1-\nu}\right)^{\xi},
$$

\footnotetext{
${ }^{15}$ See also Alvarez and Veracierto (2000).
} 
where $\xi \in(0,1)$ is a span-of-control parameter in the spirit of Lucas (1978), which reflects the diminishing returns to the entrepreneur's managerial ability.

There are two types of frictions. The first type is the search frictions in labor markets. Employment opportunities for nonemployed agents arrive every period with probability $\lambda$, which summarizes the efficiency of the general technologies available to firms in both sectors in reaching out to potential workers. Job offers can come from the corporate sector or the entrepreneurial sector. The job offer likelihood, however, varies across the two sectors, reflecting the underlying differences in vacancy advertising technologies in the two sectors. ${ }^{16}$ Conditional on the arrival of a job offer, the offer is from the corporate sector with probability $\gamma$. Employed agents maintain a deterministic match to a firm in the sector they are employed for the duration of their tenure. However, every period, workers can separate from their employers exogenously with probability, $\phi_{j}$, for each sector $j \in\{f, e\}$. Agents can also choose to separate from their employers voluntarily. When an agent is separated from a firm or when an agent decides to quit entrepreneurship, the agent has to stay nonemployed for at least one period before starting work again. There is no on-the-job search, and agents can receive job offers only when nonemployed. The parameters $\left\{\lambda, \gamma, \phi_{f}, \phi_{e}\right\}$ govern the frictions in the labor market.

The second type of friction is financial in nature. There are borrowing constraints for entrepreneurs. The amount of capital, $k_{t}$, an entrepreneur with assets, $a_{t}$, can access is bounded: $k_{t} \leq b a_{t}$, where $b \geq 1$ is an exogenously given borrowing limit. When $b=1$, entrepreneurs can only use their accumulated assets to finance production. The parameter $b$ is the only parameter that governs the financial frictions. Capital earns an interest rate, $r>0$, and depreciates at a rate of $\delta \in(0,1)$.

\subsection{Agents' Problems}

Because both worker and entrepreneurial ability follow stationary distributions, agents' policies and payoffs do not depend on calendar time. The time subscript $t$ is therefore omitted for the rest of the model description. The timing of events within a period is as follows. Agents first realize their current-period labor productivity. Each nonemployed agent then receives a job offer from one of the sectors. All agents then make their decisions about whether to work, become an entrepreneur, or not work. Following this decision, all entrepreneurs realize their current-period abilities and choose their inputs for production. Each agent then chooses how much to consume and save. At the end of the period, some of the employed agents get separated from their employers exogenously.

\footnotetext{
${ }^{16}$ For instance, in the corporate sector vacancies may be posted using multiple advertising media and recruiting agents, whereas in the entrepreneurial sector personal networks may be more heavily used.
} 
Let $s=(a, z, \theta)$ summarize an agent's assets, and worker and entrepreneurial ability in a period. In addition to $s$, each agent is differentiated by his current-period labor status, which can be nonemployment $(n)$, working in the corporate sector $(f)$, working in the entrepreneurial sector $(e)$, and being an entrepreneur $(m)$. Similar to $s$, define $\widetilde{s}=\left(a, z, \theta_{-1}\right)$ to be the agent's assets, worker, and entrepreneurial ability, before the current-period entrepreneurial ability, $\theta$, is known. Note that $\widetilde{s}$ is identical to $s$ except for its last element, which is the agent's previousperiod entrepreneurial ability.

Consider now an agent who was a worker in sector $j$ at the end of the previous period, or who has a job offer from sector $j$ in the current period. This agent faces the choice between work, nonemployment, and entrepreneurship. This choice is made before the current period entrepreneurial ability is realized, but with the knowledge of current worker ability and assets. One can define the expected value of this agent as

$$
E^{j}(\widetilde{s})=\max \left\{\mathbb{E}_{\theta \mid \theta_{-1}}\left[V^{j}(s)\right], \mathbb{E}_{\theta \mid \theta_{-1}}\left[V^{n}(s)\right], \mathbb{E}_{\theta \mid \theta_{-1}}\left[V^{m}(s)\right]\right\},
$$

where the expectation, $\mathbb{E}_{\theta \mid \theta_{-1}}$, is taken over all values of $\theta$ conditional on $\theta_{-1}$.

Consider next an agent who was not a worker in any sector at the end of the previous period, or who has no job offer in the current period. This agent faces the choice between nonemployment and entrepreneurship. This agent's value is given by

$$
U(\widetilde{s})=\max \left\{\mathbb{E}_{\theta \mid \theta_{-1}}\left[V^{n}(s)\right], \mathbb{E}_{\theta \mid \theta_{-1}}\left[V^{m}(s)\right]\right\} .
$$

Using (4) and (5), the value of a nonemployed agent can be written as

$$
V^{n}(s)=\max _{c, a^{\prime} \geq 0}\left\{\ln c+\beta \mathbb{E}_{z^{\prime} \mid z}\left[\lambda\left[\gamma E^{f}\left(\widetilde{s}^{\prime}\right)+(1-\gamma) E^{e}\left(\widetilde{s}^{\prime}\right)\right]+(1-\lambda) U\left(\widetilde{s}^{\prime}\right)\right\},\right.
$$

subject to the budget constraint

$$
c+a^{\prime}=(1+r) a,
$$

where $\widetilde{s}^{\prime}=\left(a^{\prime}, z^{\prime}, \theta\right)$ and $\left(a^{\prime}, z^{\prime}\right)$ denotes the next period's assets and worker ability. The expectation, $\mathbb{E}_{z^{\prime} \mid z}$, is taken over all values of $z^{\prime}$ conditional on $z$. Equation (6) reflects the fact that a nonemployed agent obtains the utility from consumption in the current period, and in the next period the expected value depends on whether a job offer is received, and the sector this offer comes from.

Denote by $w_{j}$ the wage per unit of worker efficiency in sector $j \in\{f, e\}$. The value of an agent who works in sector $j$ is given by

$$
V^{j}(s)=\max _{c, a^{\prime} \geq 0}\left\{\ln c-\alpha+\beta \mathbb{E}_{z^{\prime} \mid z}\left[\left(1-\phi_{j}\right) E^{j}\left(\widetilde{s}^{\prime}\right)+\phi_{j} U\left(\widetilde{s}^{\prime}\right)\right]\right\}
$$

subject to

$$
c+a^{\prime}=w_{j} z+(1+r) a,
$$


The value in (7) is composed of two parts. An employed agent receives a current utility from consumption that is reduced by the disutility of work. In the next period, the agent's expected value depends on whether he gets separated.

Finally, the value of an entrepreneur is

$$
V^{m}(s)=\max _{c, a^{\prime} \geq 0}\left\{\ln c-\alpha+\beta \mathbb{E}_{z^{\prime} \mid z}\left[U\left(\vec{s}^{\prime}\right)\right]\right\}
$$

subject to

$$
c+a^{\prime}=\pi(s)+(1+r) a,
$$

where the profit of the entrepreneur, $\pi(s)$, is given by

$$
\pi(s)=\max _{k, l \geq 0}\left\{\theta\left(k^{\nu} l^{1-\nu}\right)^{1-\xi}-w_{e} l-(r+\delta) k\right.
$$

subject to the borrowing constraint

$$
k \leq b a \text {. }
$$

The entrepreneurial value in (8) is composed of the current period utility that results from consumption and work, and the next period's expected value, which reflects the fact that in the next period the agent can continue to be an entrepreneur or choose to be nonemployed.

\subsection{Equilibrium}

Let $i \in\{n, f, e, m\}$ denote the labor status of an agent in any given period. In addition, let $d \in\{n, f, e, m\}$ be the "island" or "location" of the agent at the end of the previous period, in the sense that this location describes the agent's status before the next period's labor status decision is made. Also, denote by $j \in\{f, e\}$ a sector. A stationary competitive equilibrium for the model is a collection of value functions, $V^{i}(s)$, wage in each sector, $w_{j}$, an interest rate, $r$, labor supply rules, $h^{d}(\widetilde{s})$, a decision rule to be an entrepreneur, $m^{d}(\widetilde{s})$, saving and consumption rules, $a^{i}(s)$ and $c^{i}(s)$, an entrepreneur's capital and labor utilization rules, $k(s)$ and $l(s)$, and measures of agents by work status, $\Psi^{i}(s)$, such that

1. The labor supply rules, $h^{d}(\widetilde{s})$, and the decision rule to be an entrepreneur, $m^{d}(\widetilde{s})$, solve the problems (4) and (5),

2. The saving and consumption rules, $a^{i}(s)$ and $c^{i}(s)$, solve the agents' problems defined in $(6),(7)$, and (8),

3. The interest rate, $r$, and the corporate sector wage, $w_{f}$, satisfy

$$
\begin{aligned}
& r=\nu A K^{\nu-1} L^{1-\nu}-\delta, \\
& w_{f}=(1-\nu) A K^{\nu} L^{-\nu},
\end{aligned}
$$


4. The capital and labor choices, $k(s)$ and $l(s)$, solve the entrepreneur's problem in (9),

5. The measures, $\Psi^{i}(s)$, are consistent with the behavior of the agents,

6. Labor, capital, and goods markets clear

$$
\begin{array}{cc}
\int l(s) d \Psi^{m}(s)=\int z d \Psi^{e}(s) & \text { (entrepreneurial sector labor) } \\
L=\int z d \Psi^{f}(s) & \text { (corporate sector labor) } \\
K+\int k(s) d \Psi^{m}(s)=\sum_{i} \int a d \Psi^{i}(s) & \text { (capital) } \\
Y+\int y(s) d \Psi^{m}(s)=\sum_{i} \int c(s) d \Psi^{i}(s)+\delta\left(K+\int k(s) d \Psi^{m}(s)\right) & \text { (goods) }
\end{array}
$$

where $y(s)$ denotes the output of an entrepreneur.

While the corporate sector wage, $w_{f}$, depends on the representative firm's labor choice decision (11), the entrepreneurial sector wage, $w_{e}$, is the value that equates the labor demand by all entrepreneurs to the labor supply of all workers in the entrepreneurial sector, as shown in (12). The amount of capital used by the corporate sector and the entrepreneurial firms must equal the total assets of all agents in the economy, as implied by (14). Finally, the total output in the economy must account for the total consumption by agents and the replacement of the depreciated capital, as stated in (15). Appendix A outlines the algorithm used to solve for the stationary equilibrium numerically.

\section{Calibration}

The parameter values used in the calibration of the baseline model are in Table 1. Each period corresponds to one quarter. The discount rate, $\beta$, is set to 0.985 , to match an annual interest rate of $4 \%$. The process for labor productivity, $z$, has a persistence parameter of $\rho_{z}=0.97$ and an innovation standard deviation of $\sigma_{z}=0.13$, based on Heathcoate, Storesletten, and Violante (2010).

The process for the entrepreneurial ability, $\theta$, is specified to match the estimated persistence of the revenue-based productivity (TFPR) for young manufacturing firms in the U.S. economy. ${ }^{17}$ Similarly, the degree of returns-to-scale for entrepreneurial firms, $\xi$, is estimated for a panel of young manufacturing establishments. The annual values of the parameters $\left\{\rho_{\theta}, \sigma_{\theta}\right\}$, and

\footnotetext{
${ }^{17}$ The data availability precludes the calculation of TFPR for firms in the other sectors of the economy, such as retail and services.
} 
the returns-to-scale parameter, $\xi$, are estimated for the population of establishments belonging to young (age 0-5 years) versus mature firms (age 6+ years) separately. The estimation is based on the econometric methodology used in Abraham and White (2006), as described in Appendix B. The methodology allows for the joint estimation of the parameters $\left\{\rho_{\theta}, \sigma_{\theta}, \xi\right\}$ for establishments of young versus mature firms. For establishments of young firms, the average annual autocorrelation for $\theta$ is estimated to be $\rho_{\theta}=0.3$, with an innovation standard deviation of $\sigma_{\theta}=0.18$, across industries. The span-of-control parameter, $\xi$, has an average estimated value of 0.88 for establishments of young firms across industries. This value is smaller than the corresponding estimate for mature firms' establishments (around 0.97), suggesting a lower span-of-control for young firms' establishments. ${ }^{18}$

Following Kitao (2008) and Buera and Shin (2011), the borrowing constraint parameter, $b$, is set so that an entrepreneur can borrow up to $50 \%$ of his assets. Based on the business-cycle literature, the capital's share of output, $\nu$, is set to 0.36 , and the quarterly depreciation rate, $\delta$, is taken to be 0.015 , which corresponds to an annual depreciation rate of 0.06 . The productivity of the corporate sector, $A$, is normalized to $\exp (-1)$.

To simplify the calibration procedure, the separation rates for the two sectors are assumed to be identical: $\phi_{e}=\phi_{f}=\phi .{ }^{19}$ The remaining parameters, $\{\alpha, \lambda, \gamma, \phi, \mu\}$, are chosen to achieve five different targets that constitute a system of non-linear equations. While this system is simultaneous in nature and involve all relevant parameters of the model, each individual target plays an instrumental role in setting a specific parameter. The values of the targets are chosen to be the average value of the empirical counterparts for the period 1999-2001. For the disutility of labor, $\alpha$, the key target is the employment-to-population ratio (0.80). Two other targets, the share of employment in the corporate sector (85\%) and the corporate sector average earnings premium $(17 \%)$, are important in pinning down a value for the job offer rate from the corporate sector, $\gamma \cdot{ }^{20}$ The job finding rate, $\lambda$, and the job separation rate, $\phi$, are set so that the entrepreneurial sector's share of total nonemployment-to-employment (N-to-E) and employment-to-nonemployment (Eto-N) transitions match their respective values in the data: $23 \%$ and 21\%, respectively. Finally, the fraction of entrepreneurs, $3 \%$, is targeted in assigning a value to the productivity parameter, $\mu$. The fraction, $3 \%$, is an estimate based on the 5.7 million employer-businesses in the Survey of Business Owners (SBO), of which 0.5 million are publicly held or not classifiable by gender,

\footnotetext{
${ }^{18}$ The estimates were similar when establishments were combined at the firm level and the estimation was redone at the firm level.

${ }^{19}$ The estimates of two different separation rates resulted in very similar equilibrium allocations. To simplify the calibration procedure, the two rates were therefore set to be equal. Nevertheless, in the experiments with the parameters of the model in Section 6, these two rates are allowed to differ.

${ }^{20}$ The corporate sector earnings premium is defined as the percentage difference between the average earnings in the corporate sector and the average earnings in the entrepreneurial sector.
} 
ethnicity, race, or veteran status. Assuming that the remaining 5.2 million employer-businesses represent entrepreneurial firms, an upper bound on the fraction of entrepreneurs in the workingage population is then about $3 \%$. The calibration procedure yields an average productivity for potential entrepreneurs that is slightly higher than the productivity of the corporate sector.

\section{Properties of the Baseline Model}

The key features of the calibrated model's equilibrium are shown in Table 2. The model does a reasonable job in matching the targeted values in the data. It produces an employmentto-population ratio of 0.77 , close to the target of 0.80 . Around $3 \%$ of the individuals choose to become entrepreneurs, a figure nearly identical to the targeted fraction. As shown in Figure 9, the agents with a higher level of entrepreneurial ability tend to become entrepreneurs. Those who become entrepreneurs also tend to accumulate higher levels of assets, as shown in Figure 10. Furthermore, entrepreneurs exhibit variation in their capital input, which has a skewed distribution as shown in Figure 11. The distribution of the labor input (in terms of efficiency units) for the entrepreneurial firms shown in Figure 12 is also highly-skewed, in line with the typical shape of the firm-level distributions of employment in empirical studies. Note that the labor input in the model (worker efficiency units) is different from the employment measure (the number of workers) typically used in empirical studies of firm size.

The features of the model discussed so far are similar to those of the other models in recent work. $^{21}$ What is new is the sectoral differences in employment and worker earnings. The model's main distinguishing aspect, heterogeneous labor markets, enables it to provide further insight to the functioning of the labor markets and the nature of worker sorting. This aspect generates patterns that are broadly consistent with the behavior of the key metrics for the U.S. labor market. For example, in the baseline model, $13 \%$ of the employees work for young firms, close to the value of $15 \%$ in the data. The model also delivers a corporate earnings premium. The average worker earnings in the corporate sector is about $17 \%$ more than that in the entrepreneurial sector, almost identical to the targeted value. Note that the average earnings in each sector depends on the distribution of worker productivity $(z)$ in each sector, as well as the wages per efficiency units of labor $\left(w_{e}, w_{f}\right)$. The values for $w_{e}$ and $w_{f}$ are obtained in the calibrated model's equilibrium, but there is no observable target to discipline their values. The wage per efficiency unit of labor in the corporate sector, $w_{f}$, turns out to be 0.60 , as opposed to $w_{e}=0.48$ in the entrepreneurial sector. In other words, the corporate sector offers about $25 \%$ higher wage per worker efficiency unit. The average worker productivity, on the other hand, is higher in the entrepreneurial sector

\footnotetext{
${ }^{21}$ Some of recent work includes, among others, Quadrini (2000), Cagetti and De Nardi (2004), Kitao (2008), Buera and Shin (2011), and Bassetto, Cagetti, and De Nardi (2013).
} 
(1.65), compared with the corporate sector (1.57). That is, a worker in the entrepreneurial sector is about $5 \%$ more productive, on average, than a worker in the corporate sector.

If young firms pay lower wages per efficiency unit, why does anyone work for young firms at all? The baseline model provides an answer for this key question. Figure 13 shows the distribution of workers' assets in the entrepreneurial and corporate sectors. The distribution in the entrepreneurial sector is much more skewed, with a high mass in very low asset levels. The last two rows of Table 2 indicate that average assets of the workers in the corporate sectors is nearly three times that of the workers in the entrepreneurial sector. Because nonemployed individuals with low assets are not wealthy enough to secure a smooth stream of consumption while unemployed, they cannot afford the luxury of rejecting a job offer in the entrepreneurial sector and wait until a job offer from the corporate sector arrives. In other words, the opportunity cost of waiting for a corporate offer is too high for these individuals. This does not imply that workers in the entrepreneurial sector are necessarily less productive than their corporate counterparts. Many productive individuals with low assets choose to work for the entrepreneurial sector rather than waiting for a corporate job offer. The relatively high productivity of such individuals allows them to make large enough earnings even at the lower wage rate per efficiency unit the entrepreneurial sector provides - a higher opportunity cost. As a result, workers in the entrepreneurial sector are more productive on average. Figure 14 illustrates the productivity distribution of workers in each sector. While the means of the two distributions differ, the differences between the shapes of the two distributions are not as pronounced as in the case of assets in Figure 13. It is important to note that to generate the sorting of workers to sectors, the model does not rely on any inherent preferences for work in the entrepreneurial sector. It also does not require the presence of other benefits that may be offered to workers by entrepreneurs to compensate for lower earnings, such as profit sharing, stock options, or flexible work schedules.

The model also produces a plausible value for the entrepreneurial firms' share of total transitions from nonemployment to employment, at 0.17 compared with 0.23 in the data. It also comes very close to the observed entrepreneurial firms' share of total employment to nonemployment flows, generating a value of 0.22 versus the target, 0.21 . The quarterly interest rate, $r=0.0104$, is also nearly identical to its target of 0.01 .

\section{Evidence on Worker Sorting by Assets}

A key feature of the baseline model is the difference in the average asset holdings of workers in young versus mature firms. As discussed in the previous section, this difference emerges as a result of the sorting of workers into sectors based on their assets: workers with lower assets tend to take jobs in the entrepreneurial sector. It is important to check whether the sorting in the 
model based on assets is consistent with what is observed in the data available.

One drawback in taking the model's prediction about worker assets to data is that household survey data that include information on assets typically do not contain information on the age of a worker's employer. Towards addressing this deficiency, the wealth data for workers collected in the Survey of Income and Program Participation (SIPP) are merged with the LEHD data that captures employer-specific characteristics for those workers. In particular, the responses from the Asset and Liabilities Topical Module collected in several waves of the 2001, 2004, and 2008 SIPP Panels are used to create a net worth variable, excluding housing equity. The constructed net worth variable is used as the empirical counterpart to the assets of workers defined in the model. SIPP workers employed during these waves are linked to the LEHD data. For workers holding more than one job during the relevant quarter, firm age pertains to the firm where worker earnings were the greatest among all jobs held in that quarter. The sample is restricted to prime age males with ages 25-64 who are not entrepreneurs, to be consistent with the baseline model's calibration.

Figure 15 shows the trend in the ratio of the average net worth of workers at mature firms to that of workers at young firms for the quarters available. The figure indicates that the average net worth of workers in mature firms is approximately 1.3 times that of workers in young firms between 2001-2004. The ratio then increases thereafter to about 2.2 in 2010-2011. That is, workers in mature firms have, at the mean, twice as many assets as workers in young firms. The gap has increased since 2004. Workers in young firms fared worse over time in terms of net worth, compared to their counterparts in mature firms. Note also that the ratio of the average assets in the baseline model is 2.7 (see Table 2), which is somewhat higher than the range of values observed for the net worth ratio during the 2001-2011 period.

\section{$7 \quad$ What is behind the Decline in Entrepreneurship?}

Several hypotheses have been put forth for the causes of the decline in entrepreneurship. The goal of this section is to evaluate the relevance of some of these hypotheses using the model's framework. The approach is to change key parameters of the model from their baseline values one at a time and compare the resulting stationary equilibrium with the baseline. The goal is to see whether the results of these experiments can qualitatively replicate the trends documented in Section 2.

One hypothesis behind the decline in entrepreneurship is that changes in workers' job search technologies and firms' vacancy posting and hiring technologies altered labor market frictions in a way to put entrepreneurial firms at a disadvantage relative to mature ones. ${ }^{22}$ Related to

\footnotetext{
${ }^{22}$ See Decker, Haltiwanger, Jarmin, and Miranda (2014a) for a discussion. Recent work on these issues include
} 
this hypothesis, it is important to note that lower worker mobility across firms, particularly for younger workers, has accompanied the decline in entrepreneurship. Given that young firms disproportionately draw their labor force from young and nonemployed individuals, the two trends are not independent. Increasing labor market frictions may have made it more difficult for young firms to attract the desired type of workers compared to mature firms.

Another potential reason behind the decline is increasing financial frictions for entrepreneurs. Recent research has focused on various implications of a tighter credit environment for businesses in recent decades, which was aggravated with the onset of the Great Recession. ${ }^{23}$ For instance, the gradual disappearance of small banks and their loans to small businesses may have constituted a barrier to entry for entrepreneurs. Loss of personal savings and housing assets during the Great Recession may also have exacerbated the decline in entrepreneurial business formation. In addition to impeding entry, an increasingly limited amount of credit can also lead entrepreneurs to operate below their efficient scale by inhibiting business expansion.

Another hypothesis for the decline has to do with the supply of entrepreneurs. Some policies that curb the availability of able entrepreneurs may contribute to the underwhelming performance of the entrepreneurial sector in recent years. For instance, Hathaway and Litan (2014b) argue that immigration policy in the U.S. may have limited the supply of skilled entrepreneurs. Similarly, increasing costs of education, training, and more generally, human capital accumulation, can also reduce the pool of skilled entrepreneurs. To the extent that these considerations restrict the number and quality of entrepreneurs available, the entrepreneurial sector may have taken a hit.

Changes in the broader business climate may also have adversely affected new business formation and expansion. Business climate can include factors such as regulations, taxes, and other policies which can put constraints on an entrepreneur's initial scale and subsequent growth. These factors can also operate in a way to reduce new business formation and prevent reallocation of resources from less-productive to more-productive businesses. ${ }^{24}$

Other potential explanations include an increase in firms' adjustment costs to shocks, or changes in the way firms respond to shocks. For example, mature, large firms may be able to better absorb shocks with the help of their multi-location network of distribution and production, which also facilitate a greater complementarity with advanced production and communication Cairo (2013), who analyzes the role of increasing training costs on job reallocation.

${ }^{23}$ See, for instance, Haltenhof, Lee, and Stebunovs (2012) for a study of the effects of tighter bank lending on consumers and firms. Other channels, such as the effects of the reduced housing assets of consumers who are potential entrepreneurs, have also been explored. See Decker (2014) for an analysis of this channel.

${ }^{24} \mathrm{~A}$ large body of work focus on the nature of misallocations introduced by policies distorting the efficient allocation of inputs across firms as well as the policies distorting the efficiency of the entry and exit processes. See, e.g., Hsieh and Klenow (2009), Barseghyan and Diceccio (2009), Guner, Ventura, and Yi (2008). 
technologies. ${ }^{25}$ A higher intensity of competition from mature, large firms is also a factor in the decline of entrepreneurial businesses, though this consideration is certainly not a recent one. ${ }^{26}$ In addition, demographic shifts in the form of an aging U.S. population may have also played a part in the declining dynamism of the entrepreneurial sector, as individuals tend to become entrepreneurs earlier in their life-time than later. ${ }^{27}$

The experiments with the parameters of the model aim to understand the relevance of some of the hypotheses discussed above. The results of the experiments are collected in Table 3. The experiments are divided into three broad sets, each focused on assessing the ability of a major ingredient of the model to account for the observed trends. The first set focuses on the role of labor market frictions. The first experiment in this set reduces the job finding rate, $\lambda$, to simulate an environment where job offers arrive at a lower rate. Alternatively, it takes longer, on average, to find a job. The second experiment in this set increases the probability of receiving a job offer from the corporate sector, $\gamma$. This experiment aims to understand the effects of an increasing dominance of established firms in the labor market in terms of reaching out to potential employees. This dominance may result, for instance, from their use of more advanced technologies in advertising vacancies and recruiting. Finally, the third experiment in labor market frictions increases the exogenous job separation probability in the entrepreneurial sector. In the baseline model, the separation rates are the same for the two sectors. This exercise seeks to understand what happens if jobs are destroyed at a higher rate in the entrepreneurial sector or if the jobs in the entrepreneurial sector are more temporary in nature.

The second set of experiments considers the role of financial frictions. The borrowing constraint is the only channel through which financial frictions work in the model. The only experiment in this category decreases the borrowing parameter, $b$, so that the entrepreneurs rely solely on their savings to finance their businesses. By limiting the entrepreneurs to their accumulated assets, this exercise explores the consequences of tighter financial constraints at their extreme. This exercise is relevant for understanding the effects of a tighter credit environment for entrepreneurs.

The final set of experiments explores the roles of entrepreneurial ability and scale. The first experiment in this category reduces the average productivity of entrepreneurs, $\exp (\mu)$. This shift in the mean is implemented as a lower productivity for entrepreneurs in a first-order stochastic

\footnotetext{
${ }^{25}$ For instance, the emergence and dominance of retail chains in the U.S. are in part driven by the diffusion of advanced technologies, such as bar codes and computers (see, e.g., Holmes (2001)).

${ }^{26}$ The classical example of this type of competitive effect is the Walmart's impact on mom-and-pop stores (see, e.g. Basker (2009)).

${ }^{27}$ For the connection between aging and entrepreneurship, see, e.g., Liang, Wang, and Lazear (2014), Stangler (2013) and Levesque and Minniti (2006). Liang, Wang, and Lazear (2014) find significant negative effects of aging on business formation rate across countries.
} 
sense. The goal of this experiment is to simulate the effects of a decline in the supply of able entrepreneurs. The second experiment reduces the returns-to-scale parameter for entrepreneurial

production, $\xi$. This decline is meant to approximate, in a reduced form, an environment where the efficient scale of an entrepreneur is lower due to policies and regulations that make business expansion more difficult.

In interpreting the results of the experiments, the exact magnitudes of the changes in the key variables from their baseline values should not be the focus. The parameter values used in the experiments are not chosen to match any trends for the key variables. After all, the parameters that are altered in the experiments are unobserved, so there is no exact empirical guidance on how much they changed over time. What is more important is the direction of the changes in the key variables and whether these directions are consistent with the observed trends for the U.S. economy.

\subsection{Labor Market Frictions}

\subsubsection{Lower Job Finding Rate}

In the baseline model, the job finding probability, $\lambda=0.96$, is high. This high probability results in $96 \%$ of all individuals who are unemployed being offered a job in each quarter. An implication is that persistent unemployment is highly voluntary in the baseline model. Most individuals are either unemployed because they have a substantial amount of assets and are enjoying the benefits of leisure, or because they are waiting for an offer from the high-wage corporate sector. In this experiment, the job finding rate is lowered to $\lambda=0.80$, so that a lower fraction of nonemployed individuals receive job offers in any given period. Equivalently, it takes longer on average for an individual to receive a job offer.

A lower value of $\lambda$ leads to some key changes compared to the baseline case. First, the employment-to-population ratio falls, from 0.78 to 0.74 , as a result of more scarce job offers. Second, many individuals who do not receive job offers are pushed to entrepreneurship. The fraction of entrepreneurs increases from $3 \%$ of the population in the baseline model to about $5 \%$, as even workers with low entrepreneurial ability choose to become entrepreneurs rather than experience longer spells of nonemployment. Third, the employment in the entrepreneurial sector rises from $13 \%$ to about $16 \%$. At the same time, there is a lower corporate earnings premium of $12 \%$, instead of $17 \%$ in the baseline model. The decline in the corporate earnings premium, the increase in the fraction of entrepreneurs, and the share of employment in the entrepreneurial sector are not consistent with the trends documented in Section 2. A low overall job finding rate alone cannot explain many of the changes observed in the U.S. entrepreneurial sector in recent years. 


\subsubsection{Lower Job Offer Rate from the Entrepreneurial Sector}

For the baseline case, the parameter, $\gamma$, is set so that a job offer from the corporate sector is more likely. A nonemployed individual receives an offer from the corporate sector with probability 0.57 , giving the corporate sector a slight advantage in hiring. In this experiment, the likelihood that an offer comes from the corporate sector is increased, from 0.57 to 0.80 . The resulting decline in the job finding rate in the entrepreneurial sector has a strong negative effect on entrepreneurship. Only $2 \%$ of agents decide to become entrepreneurs, compared to $3 \%$ in the baseline model. The share of employment in the entrepreneurial sector also shrinks to $8 \%$, compared to $13 \%$, in the baseline model. At the same time, however, corporate earnings premium declines to about $3 \%$, from its baseline value of $17 \%$. The corporate sector has now a much more captive market for its labor. It therefore offers a lower wage per efficiency unit, which also results in lower average worker earnings. This experiment captures some of the features that the U.S. economy exhibited in recent years. The decline in the rate of entrepreneurship and the share of employment in the entrepreneurial sector are consistent with the trends. What is not consistent with the stylized facts is the erosion of the corporate earnings premium, which exhibits an increase in recent years, as discussed in Section 2.

\subsubsection{Higher Job Separation Rate in the Entrepreneurial Sector}

The exogenous separation rates in the baseline model are set to be equal: $\phi_{e}=\phi_{f}=0.17$. Suppose now that the separation rate in the entrepreneurial sector, $\phi_{e}$, increases from its baseline value of 0.17 to 0.30 , while the separation rate in the corporate sector stays the same, $\phi_{f}=0.17$. This increase in separation rate means that jobs have much lower duration in the entrepreneurial sector on average. As shown in Table 3, in response to this change the fraction of entrepreneurs increases from its baseline value of $3 \%$ to $4 \%$, and the share of employment in the entrepreneurial sector is almost the same as in the baseline. The corporate earnings premium declines from $17 \%$ to $9 \%$, while the wages per efficiency unit do not change much from their baseline values. The workers in the entrepreneurial sector are now much more productive on average compared to the corporate sector. Since jobs have a much shorter tenure in the entrepreneurial sector, only highly productive nonemployed individuals tend to take these jobs and make higher relative average earnings. Note also that the average size (labor input) of entrepreneurs increases, which is inconsistent with the decline in the average employee size of entrepreneurial firms. These patterns suggest that even a large change from the baseline in the separation rate for workers in the entrepreneurial sector does not lead to the observed decline in the fraction of entrepreneurs and the share of employment in the entrepreneurial sector, and the observed increase in the corporate earnings premium. 
The three experiments in this section suggest that it is not straightforward to account for the recent trends in entrepreneurship based solely on the changing frictions in the labor market. It is important to emphasize that in all three experiments the baseline model's feature of worker sorting based on assets survives, though the ratio of average worker assets in corporate versus entrepreneurial sector becomes lower. This drop in the ratio of average assets is not consistent with the trends in Figure 15, which points to an increase in this ratio.

\subsection{Financial Frictions}

\subsubsection{Lower Borrowing Limit}

In this experiment, the amount of borrowing is reduced to zero $(b=1)$ to simulate an economy where entrepreneurs are not allowed to borrow at all. The effect of this tightening in borrowing is felt on all aspects of entrepreneurship, as seen in Table 3. Lower borrowing limit discourages entrepreneurship: the fraction of entrepreneurs decreases to $2 \%$ from $3 \%$ in the baseline model. There is also an accompanying fall in the share of employment in the entrepreneurial sector, which goes down to $9 \%$ from $13 \%$ in the baseline model. The corporate earnings premium also rises sharply from its baseline value of $17 \%$ to $46 \%$. In addition, the average labor input of entrepreneurial firms falls from its baseline value, consistent with the trends in average employment in young firms. Worker sorting into sectors based on assets also prevails in this experiment, and the gap between the average assets for workers in the two sectors becomes even larger. The average assets of the workers in the corporate sector is almost 4 times that of the workers in the entrepreneurial sector. This ratio is 2.7 in the baseline. The increase in the ratio is consistent with the trends in Figure 15. Overall, an increase in financial frictions is able to replicate qualitatively nearly all of the key trends in the entrepreneurial sector in the U.S. in recent years. This experiment suggests that tighter financial constraints entrepreneurs face in the aftermath of the Great Recession may have relevance in accounting for the recent changes observed in the U.S. economy.

\subsection{Entrepreneurial Technology and Ability}

\subsubsection{Lower Entrepreneurial Quality}

To assess the implications of a reduction in the quality of entrepreneurs, this experiment reduces the average entrepreneurial productivity, $\exp (\mu)$, from its baseline value of 0.37 to 0.33 . This decline is equivalent to a lower entrepreneurial ability, in a first-order stochastic sense. The degradation in the quality of entrepreneurs leads to much lower fraction of entrepreneurs in the economy. A mere $1 \%$ of the individuals are now entrepreneurs, as opposed to $3 \%$ in the baseline 
model. The share of employment in the entrepreneurial sector also falls sharply to $6 \%$, from $13 \%$ in the baseline case. Corporate earnings premium also increases substantially, to $77 \%$ from its baseline value of $17 \%$. Note also that there is now a decline in the average productivity of workers in the entrepreneurial sector compared to the baseline, while the average productivity of workers in the corporate sector remains essentially the same. In other words, a degradation in the quality of entrepreneurs is accompanied by a degradation in the quality of workers who work for them. The ratio of average assets of workers in the corporate to that of the workers in the entrepreneurial sector is also now much higher, at a value of 7.0 compared to the baseline value of 2.7. Overall, a decline in the average productivity of entrepreneurs is capable of mimicing many facets of the decline in entrepreneurship in the U.S. in recent years.

\subsubsection{Lower Efficient Scale for Entrepreneurs}

This final experiment explores what happens if entrepreneurial firms have lower efficient scale, which may reflect, in a reduced form, the effects of policies and regulations that inhibit the expansion of entrepreneurial businesses. The evidence in Section 2 indicates that the average employee size of entrepreneurial firms has declined over time, both in absolute terms and relative to mature firms. One possible explanation is that business expansion has gradually become harder. As a result, entrepreneurs increasingly operate smaller firms. To explore this possibility, the returns-to-scale parameter, $\xi$, is reduced to 0.80 , from its baseline value of 0.88 . This reduction has a strong negative effect on many aspects of entrepreneurship. The fraction of entrepreneurs falls to $2 \%$, from $3 \%$ in the baseline case. The corporate sector earnings premium is now also much higher: $79 \%$ compared with $17 \%$ in the baseline case. The corporate sector becomes more attractive for nonemployed individuals, and they are more willing to wait for job offers from that sector, instead of more readily accepting job offers from the entrepreneurial sector. As a result, the share of employment in the entrepreneurial sector declines to $5 \%$ compared with $13 \%$ in the baseline model. The average labor input of an entrepreneurial firm also falls substantially to 1.04 from its baseline value of 3.01. As in the case of a fall in the average productivity of entrepreneurs, a reduction in the efficient scale for entrepreneurs is also able to replicate qualitatively the observed trends in the entrepreneurial sector in recent years. Similar to the experiments with labor market frictions and borrowing limit, the model's key property that workers sort across sectors based on assets emerges as a robust feature in the two experiments in this section. However, in both experiments worker sorting based on assets becomes much more pronounced compared to the baseline case. 


\section{Conclusion}

Young and mature firms exhibit marked differences in the types of their workers, and the earnings they make. Compared with mature firms, young firms hire younger workers who disproportionately come from the ranks of nonemployment and provide lower earnings to these workers. Furthermore, in recent years the number, the employment share, the average employee size and worker earnings of young firms have all declined, both in absolute terms and relative to mature firms. To explore these facts, this paper has proposed a dynamic model of entrepreneurship. The model introduces a new feature to recent models of entrepreneurship: separate labor markets for entrepreneurs and the corporate sector, with different search frictions. This framework is used to account for a variety of new facts about employment and earnings at young versus mature businesses over the last couple of decades.

The calibrated model's equilibrium offers an answer to the central question of who works for whom. The differences in labor market frictions and production technologies across the two sectors lead to different sectoral wages per unit of worker efficiency. Individuals who are looking for work but less wealthy more readily take up job offers from the low-paying entrepreneurial sector, instead of waiting for a corporate job offer. This mechanism results in a sorting of workers across the two sectors based on wealth, and also on worker productivity. The model can account for the differences in the employment shares and the average earnings of workers in the two sectors observed in the data. The model's key prediction that workers sort based on assets into the sectors finds support in the data pertaining to the net worth of individuals working in young and mature firms. Workers in young firms indeed possess, on average, lower assets than workers in mature firms.

As an application of the model, potential mechanisms behind the recent decline in the entrepreneurial sector of the U.S. are explored. The experiments with key parameters of the model suggest that an increase in financial frictions or a decline in the quality of entrepreneurs or their efficient scale can account qualitatively for many of the observed trends. An increase in labor market frictions for the entrepreneurial sector is not as successful in generating the trends. A challenge for future work is to quantify the exact contribution of each of the potential channels to the decline in entrepreneurship.

\section{References}

[1] Abowd, John M., Bryce E. Stephens, Lars Vilhuber, Fredrik Andersson, Kevin L. McKinney, Marc Roemer, and Simon D. Woodcock. 2009. "The LEHD Infrastructure Files and the Creation of the Quarterly Workforce Indicators" In Producer Dynamics: New Evidence from 
Micro Data, 68, Studies in Income and Wealth, ed. Timothy Dunne, J.Bradford Jensen and Mark J. Roberts, 149-230. Chicago: University of Chicago Press.

[2] Abraham, Arpad, and Kirk White. 2006. "The Dynamics of Plant-Level Productivity in U.S. Manufacturing", Working Papers 06-20, Center for Economic Studies, U.S. Census Bureau.

[3] Alvarez, Fernando, and Marcelo Veracierto. 2000. "Labor-Market Policies in an Equilibrium Search Model" In NBER Macroeconomics Annual 1999, ed. Ben S. Bernanke and Julio J. Rotemberg. Chicago, IL: University of Chicago Press.

[4] Barseghyan, Levon, and Ricardo Diceccio. 2009. "Entry Costs, Industry Structure, and Cross-Country Income and TFP Differences" Journal of Economic Theory, 106(5): 18281851.

[5] Basker, Emek. 2009. "The Economic of Wal-Mart" The New Palgrave Dictionary of Economics, Online Edition.

[6] Bassetto, Marco, Marco Cagetti, and Mariacristina De Nardi. 2013. "Credit Crunches and Credit Allocation in a Model of Entrepreneurship" NBER Working Paper \#19296.

[7] Buera, Francisco, and Yongseok Shin. 2011. "Self-Insurance vs. Self-Financing: A Welfare Analysis of the Persistence of Shocks" Journal of Economic Theory 146(3): 845-862.

[8] Brown, Charles, and James Medoff. 2003. "Firm Age and Wages" Journal of Labor Economics 21(3): 677-698.

[9] Cairo, Isabel. 2013. "The Slowdown in Business Employment Dynamics: The Role of Changing Skill Demands", Working Paper, Universitat Pompeu Fabra.

[10] Cagetti, Marco, and Mariacristina De Nardi. 2006. "Entrepreneurship, Frictions, and Wealth" Journal of Political Economy 114(5): 835-870.

[11] Castiglionasi, Fabio and Carmine Ornaghi. 2013. "On the Determinants of TFP Growth: Evidence from Spanish Manufacturing Firms" Macroeconomic Dynamics, March 2013, 17(3): $501-530$.

[12] Davis, Steven, Jason Faberman, and John Haltiwanger. 2014. "The Establishment-Level Behavior of Vacancies and Hiring" Quarterly Journal of Economics 128(2): 581-622.

[13] Davis, Steven, and John Haltiwanger. 2014. "Labor Market Fluidity and Economic Performance" Paper presented at the 2014 Federal Reserve Bank of Kansas City Economic Symposium Conference in Jackson Hole, WY. 
[14] Decker, Ryan. 2014. "Collateral Damage: Housing, Entrepreneurship, and Job Creation", Working Paper, University of Maryland.

[15] Decker, Ryan, John Haltiwanger, Ron Jarmin, and Javier Miranda. 2014a. "The Role of Entrepreneurship in US Job Creation and Economic Dynamism" Journal of Economic Perspectives 28(3): 3-24.

[16] Decker, Ryan, John Haltiwanger, Ron Jarmin, and Javier Miranda. 2014b. "The Secular Decline in Business Dynamism in the U.S." Unpublished draft, University of Maryland.

[17] Dinlersoz, Emin, Henry Hyatt, and Sang Nguyen. 2014b. "The Plant Life-Cycle of the Average Wage of Employees in U.S. Manufacturing" IZA Journal of Labor Economics 2(7): $1-23$.

[18] Dunne, Tim, Roberts, Mark, and Larry Samuelson. 1989. "The Growth And Failure Of U.S. Manufacturing Plants." Quarterly Journal of Economics, 104(4): 671-698.

[19] Goetz, Christopher, Henry Hyatt, Erika McEntarfer, and Kristin Sandusky. 2014. "Understanding Business Formation and Growth: The Potential of Linked Employee-Business Data in Entrepreneurial Research" Unpublished draft, US Census Bureau.

[20] Guner, Nezih, Gustavo Venture and Daniel Xu Yi. 2008. "Macroeconomic Implications of Size-Dependent Policies" Review of Economic Dynamics, 11(4):721-744.

[21] Haltenhof, Samuel, Seung Jung Lee, and Viktors Stebunovs. 2014a. "The Credit Crunch and Fall in Employment during the Great Recession" Journal of Economic Dynamics and Control, 43(1): 31-57.

[22] Haltenhof, Samuel, Seung Jung Lee, and Viktors Stebunovs. 2014b. "Bank Lending Channels during the Great Recession" Finance and Economics Discussion Series 2014-06. Board of Governors of the Federal Reserve System.

[23] Haltiwanger, John, Javier Miranda, and Ron Jarmin. 2009. "Business Dynamics Statistics: An Overview" Kauffman Foundation Statistical Brief.

[24] Haltiwanger, John, Javier Miranda, and Ron Jarmin. 2013. "Who Creates Jobs? Small versus Large versus Young" Review of Economics and Statistics 95(2): 347-361.

[25] Haltiwanger, John C., Henry R. Hyatt, Erika McEntarfer, and Liliana Sousa. 2012. "Business Dynamics Statistics Briefing: Job Creation, Worker Churning, and Wages at Young Businesses" Kauffman Foundation Statistical Brief. 
[26] Haltiwanger, John, Henry Hyatt, Erika McEntarfer, Liliana Sousa, and Stephen Tibbets. 2014. "Firm Age and Size in the Longitudinal Employer-Household Dynamics Data" U.S. Census Bureau Center for Economic Studies Working Paper \#14-16.

[27] Haltiwanger, John, Henry Hyatt, and Erika McEntarfer. 2014. "Cyclical Reallocation of Workers by Firm Size and Firm Wage" Unpublished draft, University of Maryland.

[28] Hathaway, Ian, and Robert Litan. 2014a. "The Other Aging of America: The Increasing Dominance of Older Firms", Brookings Institution.

[29] Hathaway, Ian, and Robert Litan. 2014b. "Declining Business Dynamism in the United States: A Look at States and Metros", Brookings Institution.

[30] Heathcoate, Jonathan, Kjetil Storesletten, and Giovanni Violante. 2010. "The Macroeconomic Implications of Rising Wage Inequality in the United States" Journal of Political Economy 118(4): 681-722.

[31] Holmes, Thomas J. 2001. "Bar Codes Lead to Frequent Deliveries and Superstores", RAND Journal of Economics, 32(4): 708-725.

[32] Hsieh, Chang-Tai, and Peter J. Klenow. 2009. "Misallocation and Manufacturing TFP in China and India", Quarterly Journal of Economics, 124(4): 1403-1448.

[33] Hyatt, Henry, Erika McEntarfer, Kevin McKinney, Stephen Tibbets, and Douglas Walton. 2014. "Job-to-Job (J2J) Flows: New Labor Market Statistics from Linked EmployerEmployee Data"Unpublished draft, US Census Bureau.

[34] Hyatt, Henry R., and James R. Spletzer. 2013. "The Recent Decline in Employment Dynamics" IZA Journal of Labor Economics, 2(5): 1-21.

[35] Huggett, Mark, and Gustavo Ventura. 1999. "On the Distributional Effects of Social Security Reform" Review of Economic Dynamics, 2(3): 498-531.

[36] Kitao, Sagiri. 2008. "Entrepreneurship, Taxation and Capital Investment" Review of Economic Dynamics 11(1): 44-69.

[37] Kölling Arnd, Claus Schnabel, and Joachim Wagner. 2002. "Establishment age and wages: Evidence from German linked employer-employee data" IZA Discussion Paper \#679.

[38] Levesque, Moren, and Maria Minniti. 2006. "The Effect of Aging on Entrepreneurial Behavior" Journal of Business Venturing, 21(2): 177-194. 
[39] Liang, James, Hui Wang, and Edward P. Lazear. 2014. "Demographics and Entrepreneurship", NBER Working paper No. 20506.

[40] Lucas, Robert, and Edward Prescott. 1974. "Equilibrium Search and Unemployment" Journal of Economic Theory, 7(2): 188-209.

[41] Lucas, Robert. 1978. "On the Size Distribution of Business Firms", Bell Journal of Economics, 2(3): 508-523.

[42] Ouimet, Paige, and Rebecca Zarutskie. 2014. "Who Works for Startups? The Relation between Firm Age, Employee Age and Growth" Journal of Financial Economics, Forthcoming.

[43] Quadrini, Vincenzo. 2000. "Entrepreneurship, Saving, and Social Mobility" Review of Economic Dynamics 3(1): 1-40.

[44] Sedlacek, Petr, and Vincent Sterk. 2014. "The Growth Potential of Startups over the Business Cycle" Unpublished draft, University College London.

[45] Stangler, Dane. 2013. "The Age of the Entrepreneur: Demographics and Entrepreneurship" with contributions from Daniel Spulber, I4J Summit, March 2013, IIIJ Innovation and Communication, Menlo Park.

[46] Tauchen, George. 1986. "Finite State Markov-Chain Approximations to Univariate and Vector Autoregressions" Economics Letters 20(2): 177-181.

\section{A Algorithm for Solving The Model's Equilibrium}

A stationary equilibrium to the model is computed using the following algorithm based on Huggett and Ventura (1999). The algorithm finds an equilibrium by iterating over value functions and decision rules over a discretized state space. Discretization of the continuous worker and entrepreneurial ability processes in (1) and (2) is done using the Tauchen (1986) algorithm with a 21-point support for the distribution implied by the process. The support is bounded below and above the mean by 2.5 times the standard deviation. The asset grid is discretized to 201 points. The spacing between points on the asset grid increases with asset levels. Asset gridpoints are placed according to $a_{1}=0, a_{j}=\psi j^{\chi}$ for $j=2, \ldots, 201$, where $\chi=3.4, \psi=\bar{a} /\left(201^{\chi}\right)$ and $\bar{a}$ is an upper bound. The algorithm is as follows.

1. Guess values for capital, $K$, and labor, $L$, in the corporate sector,

2. Calculate the values $w_{f}=(1-\nu) A K^{\nu} L^{-\nu}$ and $r=\nu A K^{\nu-1} L^{1-\nu}-\delta$. 
3. Set an initial value for the entrepreneurial sector wage: $w_{e}=w_{f}$,

4. Calculate optimal decision rules $c^{i}(s), a^{i \prime}(s), h^{d}(\widetilde{s}), m^{d}(\widetilde{s}), k(s), l(s),(i, d \in\{n, f, e, m\})$

5. Calculate $K, L$, and $w_{e}$ implied by the optimal decision rules,

6. If the values of $K$ and $L$ in Step 5 are very close (within a level of tolerance) to the values in Step 1, a stationary equilibrium has been found. Otherwise, update the guesses to the new values of $K$ and $L$ and repeat steps 1-5.

\section{B Estimation of the Parameters $\rho_{\theta}, \sigma_{\theta}$, and $\xi$}

The estimation of the decreasing returns parameter, $\xi$, for entrepreneurial firms, and the parameters for the entrepreneurial productivity process, $\left\{\rho_{\theta}, \sigma_{\theta}\right\}$, is based on the framework of Abraham and White (2006). ${ }^{28}$ The framework is particularly suitable for the task at hand, as it allows the estimation of the parameters $\left\{\rho_{\theta}, \sigma_{\theta}, \xi\right\}$ simultaneously. Consider a production function for a manufacturing establishment $i$ in the form of

$$
y_{i t}=\theta_{i t}\left(k_{i t}^{a_{k}} l_{i t}^{a_{l}} x_{i t}^{1-a_{k}-a_{l}}\right)^{\xi}
$$

which includes materials and energy, $x_{i t}$, as an input, and a productivity process $\ln \theta_{i t}=(1-$ $\left.\rho_{\theta}\right) \mu_{i}+\delta_{t}+\rho_{\theta} \ln \theta_{i t-1}+\epsilon_{t}$, where $\mu_{i}$ is an establishment-specific productivity parameter, $\delta_{t}$ is a year effect that captures general changes in productivity that apply to all establishments, and $\epsilon_{t} \sim N\left(0, \sigma_{\theta}\right)$. The parameters $\rho_{\theta}$ and $\sigma_{\theta}$ vary across industries, but not establishments. The inclusion of the materials and energy in the production function controls for the use of intermediate inputs (materials and energy) in estimating the underlying total factor productivity process. The estimation also allows for a markup, $\eta$, common to all establishments, which can be thought of as the average markup across establishments that is assumed to be constant over time. Abraham and White (2006) estimate the parameters, $\xi, \rho_{\theta}$ and $\sigma_{\theta}$ in a GMM framework using the log-linear form of the production function and the Solow residual obtained from the gross output and cost shares of the inputs. See Abraham and White (2006) or Castiglionesi and Ornaghi (2013) for a derivation of the exact model estimated.

The data used for the estimation is the U.S. Census Bureau's Annual Survey of Manufactures (ASM), which provides an unbalanced panel of manufacturing establishments for the period 1972-2009. The data include, for each establishment, annual measures of output (value of shipments) and inputs (employment, materials/energy use, capital). The age of the firm which the establishment belongs is also available. The establishments included in the ASM are typically

\footnotetext{
${ }^{28}$ Also see Castiglionesi and Ornaghi (2013) for a similar estimation methodology.
} 
of size 20 employees or more, so the parameter estimates are not representative of very small young establishments. The model yields estimates of $\xi, \rho_{\theta}$, and $\sigma_{\theta}$ for young versus mature firms at the 4-digit SIC industry level. The estimated values for young firms are then averaged across industries to be used in the calibration of the baseline model. The analysis is limited to the manufacturing sector because of the unavailability of similar data for other sectors of the economy (e.g. retail and services) to calculate the revenue-based productivity of an establishment. Note also that the estimates apply to establishments of young and mature firms, not firms. However, this is not very restrictive, because an overwhelming majority of young firms consist of only a single establishment. The results were very similar when establishments in the sample were combined based on firm affiliation.

A remark is in order for how the estimated parameters of the three-input production function in (16) are used to calibrate the model's two-factor production function in (3). In the assumed form of the production function in (16), the decreasing returns parameter, $\xi$, is the same for each of the three inputs. Because the decreasing returns parameter is common to all inputs, in the model's calibration in Section 4 the estimated decreasing returns parameter $\xi=0.88$ is applied to both inputs in (3). Similarly, the total factor productivity process is not specific to any input (i.e. Hicks neutral) in (16). Therefore, the estimated productivity process based on the three-input production function in (16) is assumed to apply to the two-factor production in (3). 
Table 1. The parameter values for the baseline model

\begin{tabular}{lcl} 
Parameter & Value & \multicolumn{1}{c}{ Target/Source } \\
\hline Disutility from labor, $\alpha$ & 0.39 & Fraction employed -16 -64 yrs old males $(0.80)$ \\
Discount rate, $\beta$ & 0.985 & Annual interest rate (0.04) (Business cycle literature) \\
Job separation rate, $\phi_{e}=\phi_{f}$ & 0.17 & Young firms' share of E-to-N transitions $(21 \%)$ \\
Job finding rate, $\lambda$ & 0.96 & Young firms' share of N-to-E transitions $(23 \%)$ \\
Corporate sector job offer rate, $\gamma$ & 0.57 & Share of employment in the corporate sector $(0.85)$ \\
Labor productivity, $\left\{\rho_{z}, \sigma_{z}\right\}$ & $\{0.97,0.13\}$ & Heathcoate et al. (2010) \\
Entrepreneurial ability (Persistence), $\left\{\rho_{\theta}, \sigma_{\theta}\right\}$ & $\{0.30,0.18\}$ & Estimated based on Abraham and White $(2006)$ \\
Entrepreneurial ability (Mean), exp $(\mu)$ & 0.37 & Fraction of entrepreneurs (3\%) \\
Productivity of the corporate sector, $A$ & 0.36 & Normalization \\
Borrowing limit, $b$ & 1.50 & Kitao (2008) \\
Capital share in production, $\nu$ & 0.36 & Business cycle literature \\
Capital depreciation rate, $\delta$ & 0.06 & Annual depreciation rate \\
Returns-to-scale in entrepreneurship, $\xi$ & 0.88 & Estimated based on Abraham and White $(2006)$ \\
\hline
\end{tabular}


Table 2. The properties of the baseline model

\begin{tabular}{lcc} 
Variable & Model & Data \\
\hline Employment-to-population ratio & 0.77 & 0.80 \\
Share of employment (Entrepreneurial) & 0.13 & 0.15 \\
Fraction of entrepreneurs & 0.03 & 0.03 \\
Average worker productivity (Corporate) & 1.57 & NA \\
Average worker productivity (Entrepreneurial) & 1.65 & NA \\
Corporate average earnings premium & 0.17 & 0.17 \\
Average labor input of entrepreneurial firms & 3.01 & NA \\
Share of E-to-N transitions (Entrepreneurial) & 0.22 & 0.21 \\
Share of N-to-E transitions (Entrepreneurial) & 0.17 & 0.23 \\
Interest rate, $r$ & 0.010 & 0.010 \\
Wage per efficiency unit, $w_{f}$ (Corporate) & 0.60 & NA \\
Wage per efficiency unit, $w_{e}$ (Entrepreneurial) & 0.48 & NA \\
Average worker assets (Corporate) & 14.63 & NA \\
Average worker assets (Entrepreneurial) & 5.39 & NA \\
\hline
\end{tabular}


Table 3. Simulation analysis of the decline in entrepreneurship

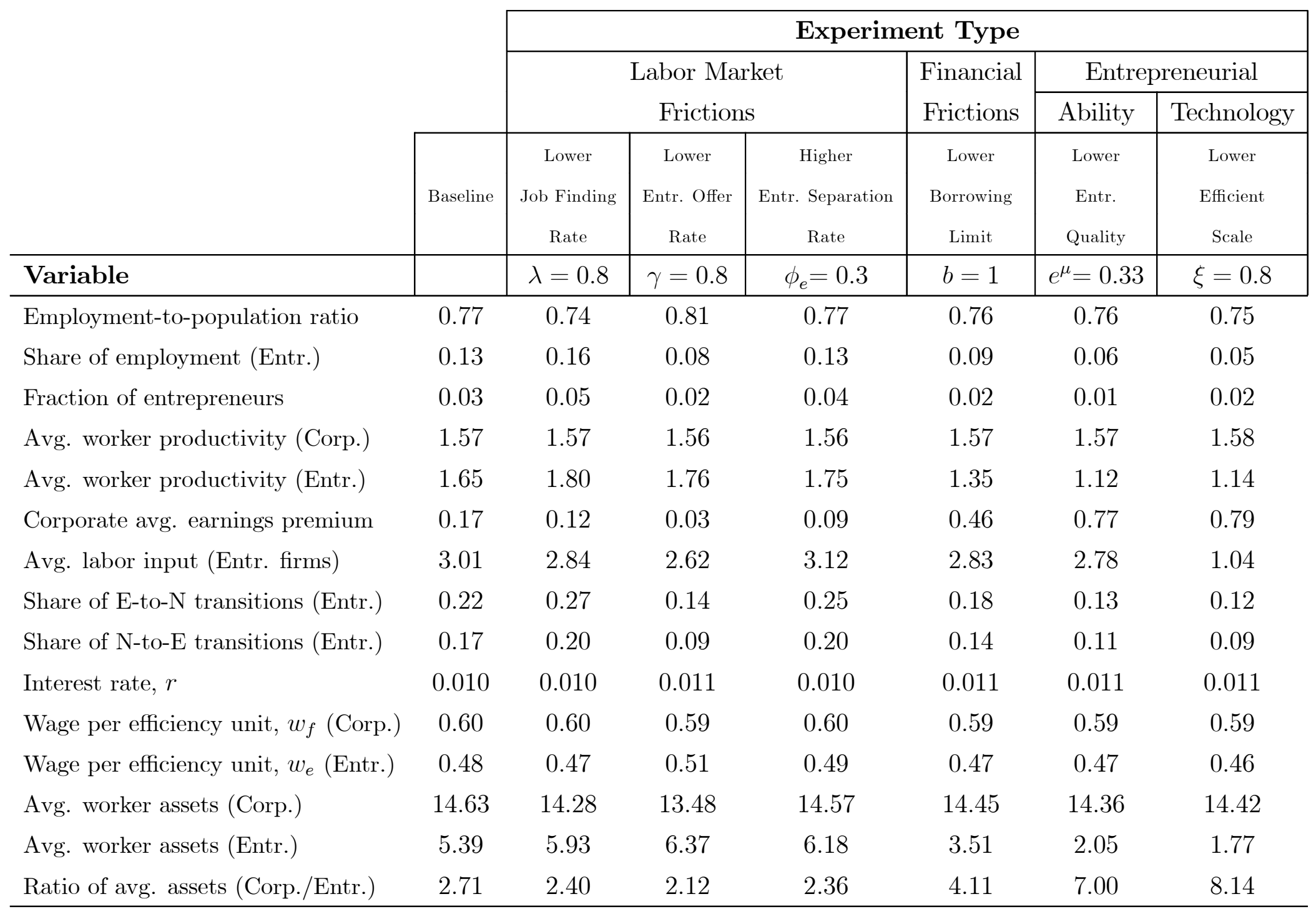




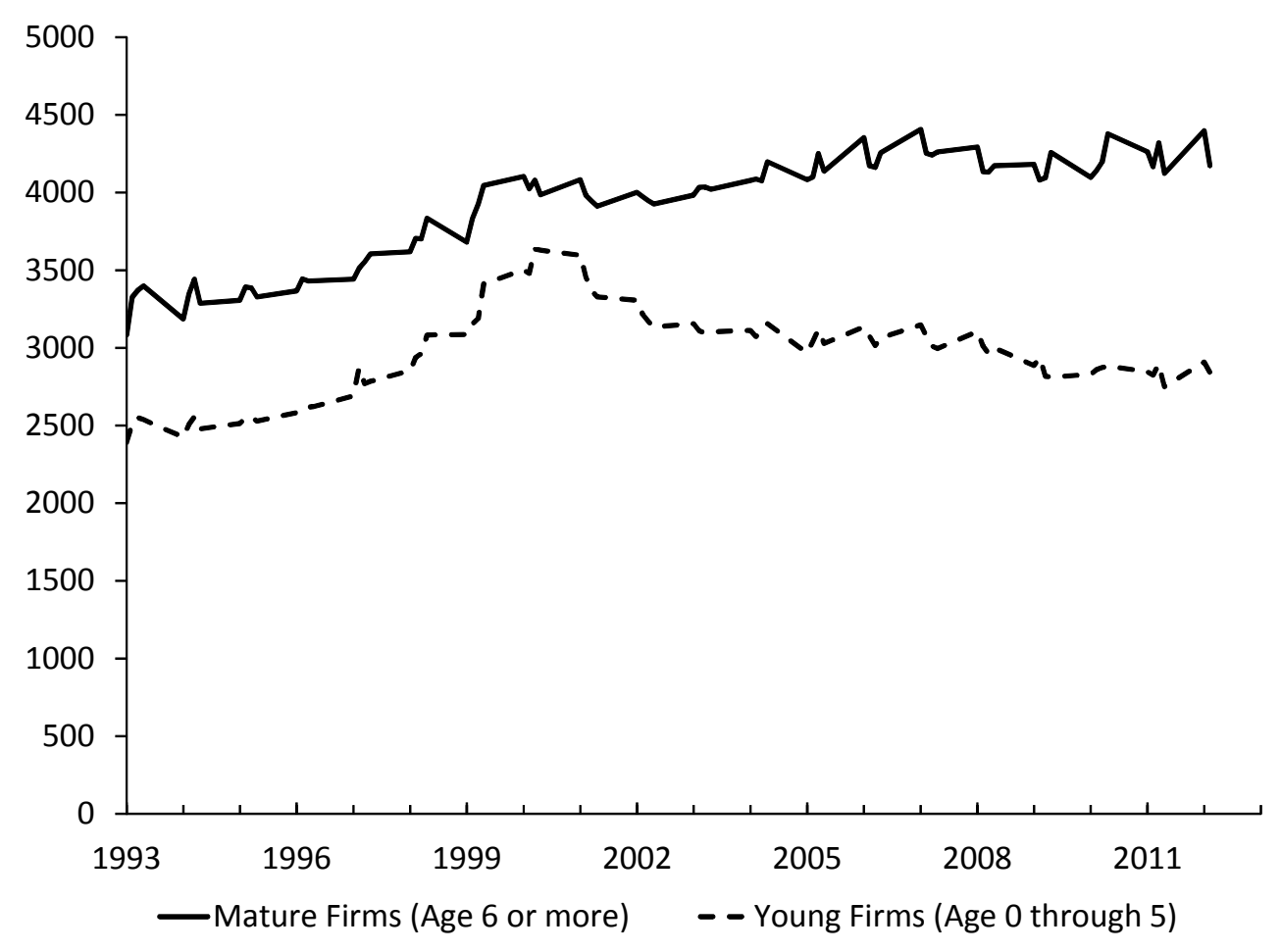

Figure 1: Average monthly worker earnings (in 2009 dollars, seasonally adjusted)

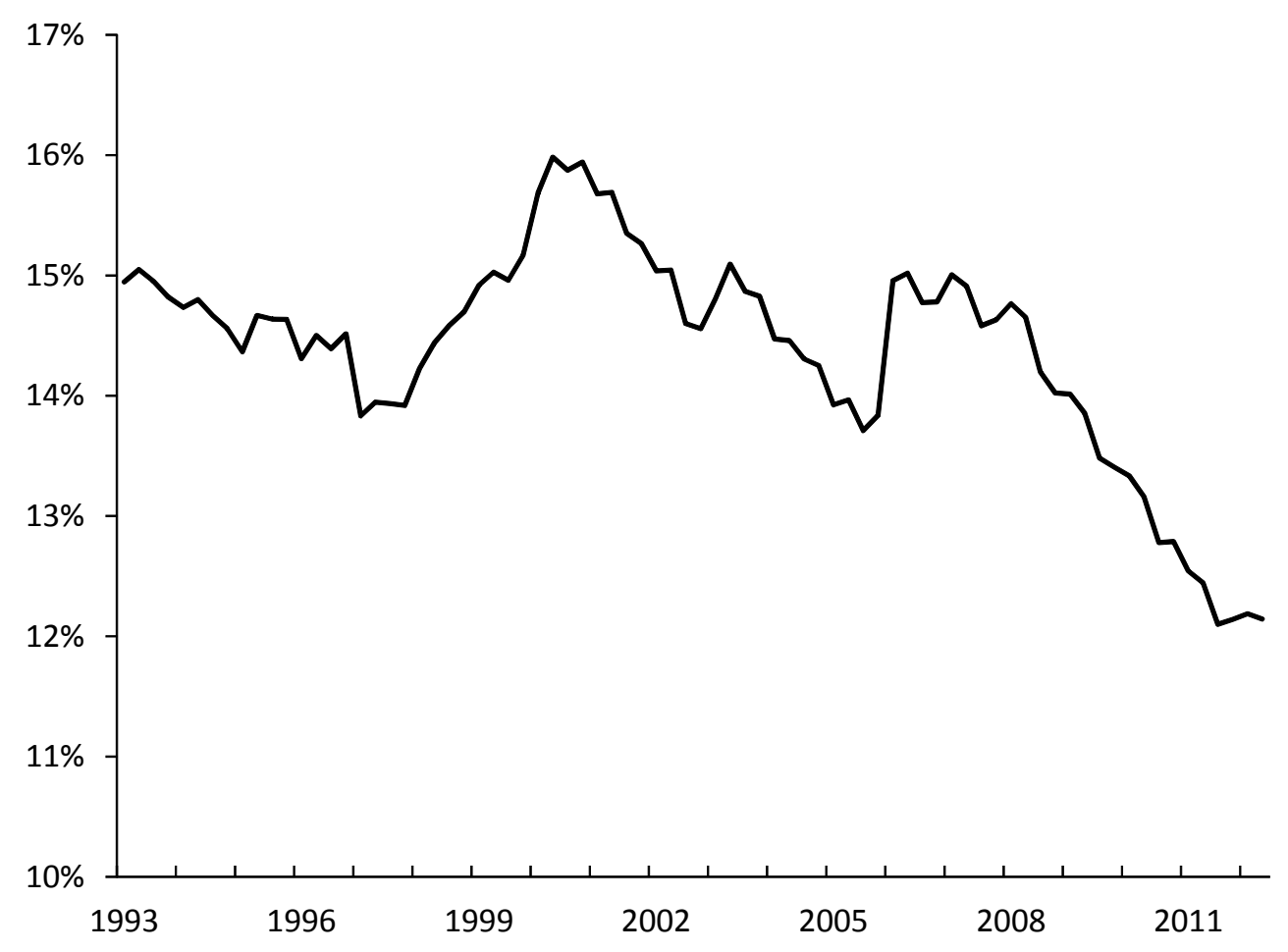

Figure 2: Employment share of young firms 


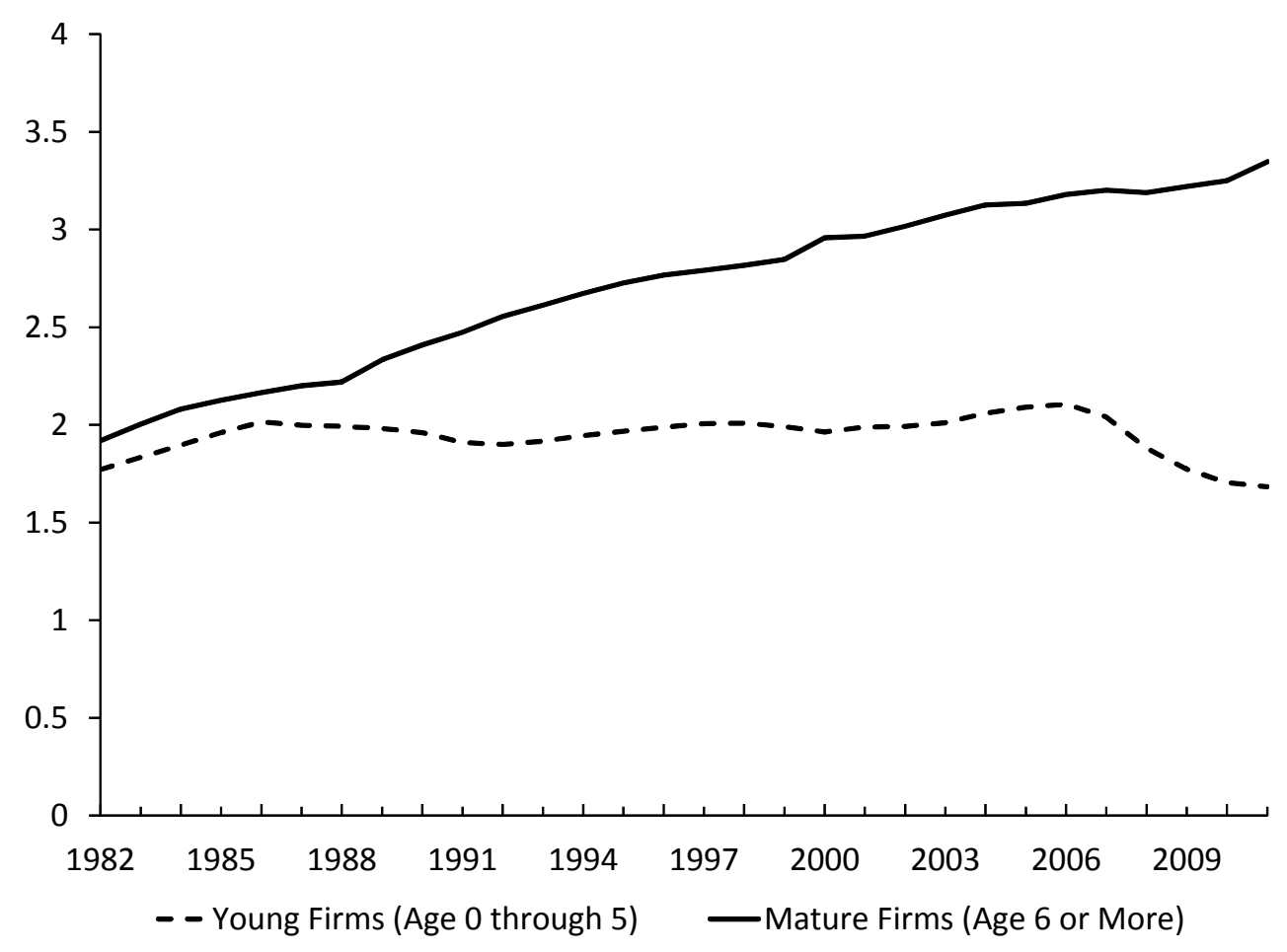

Figure 3: Firm counts (in Millions)

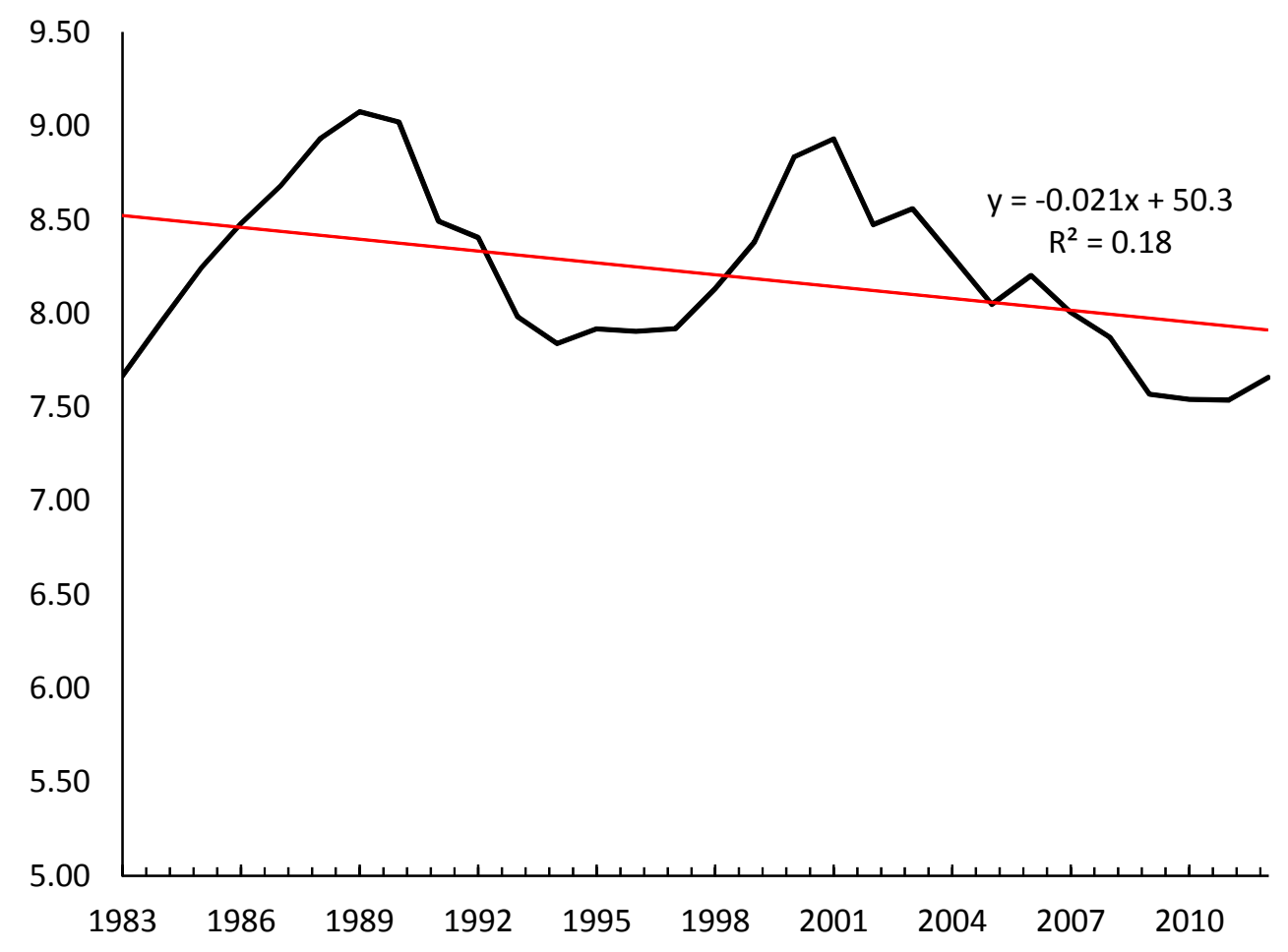

Figure 4: Average size of young firms (employees per firm) 


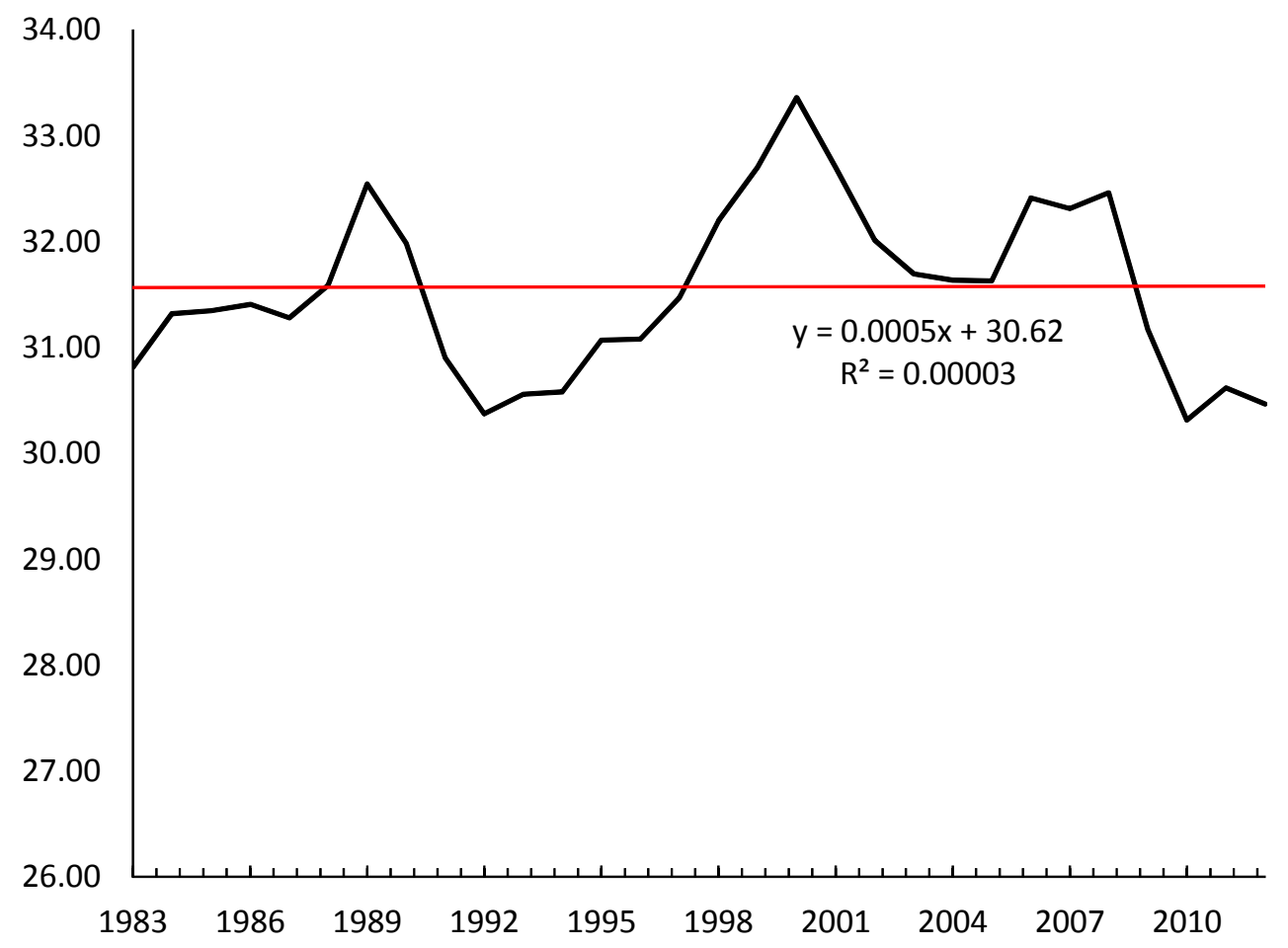

Figure 5: Average size of mature firms (employees per firm)

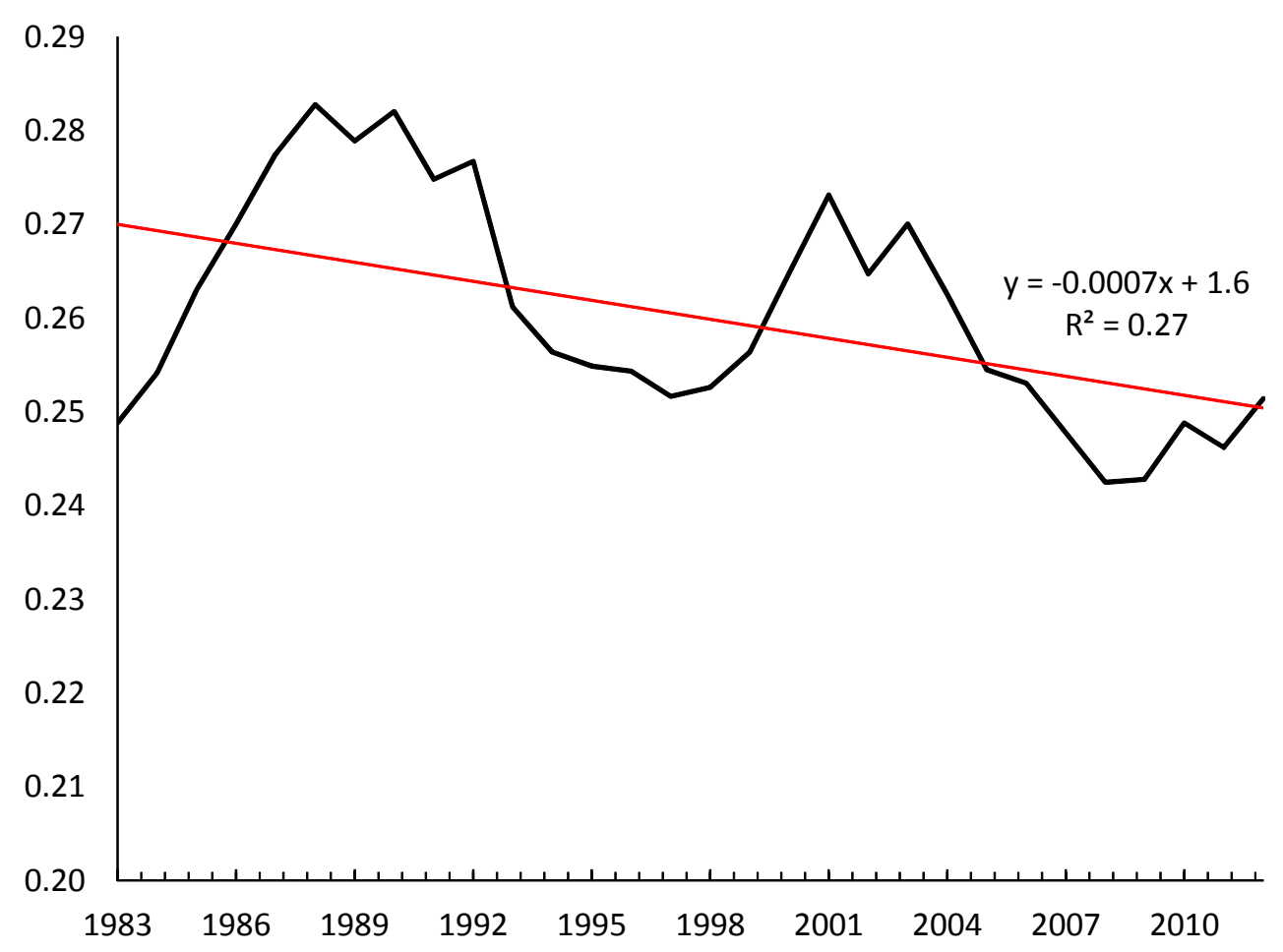

Figure 6: Relative average size of young firms 


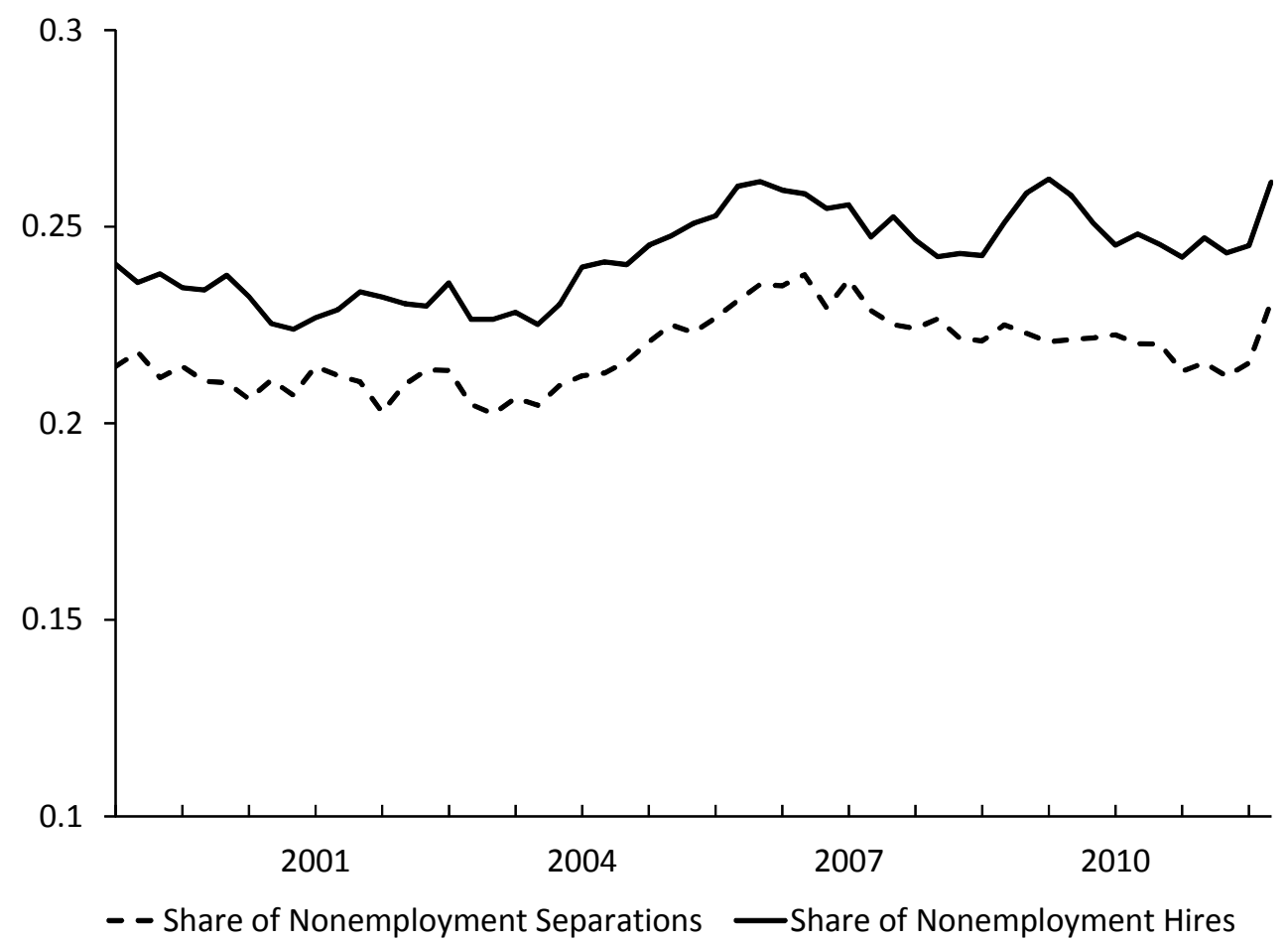

Figure 7: Shares of nonemployment hires and separations for young firms

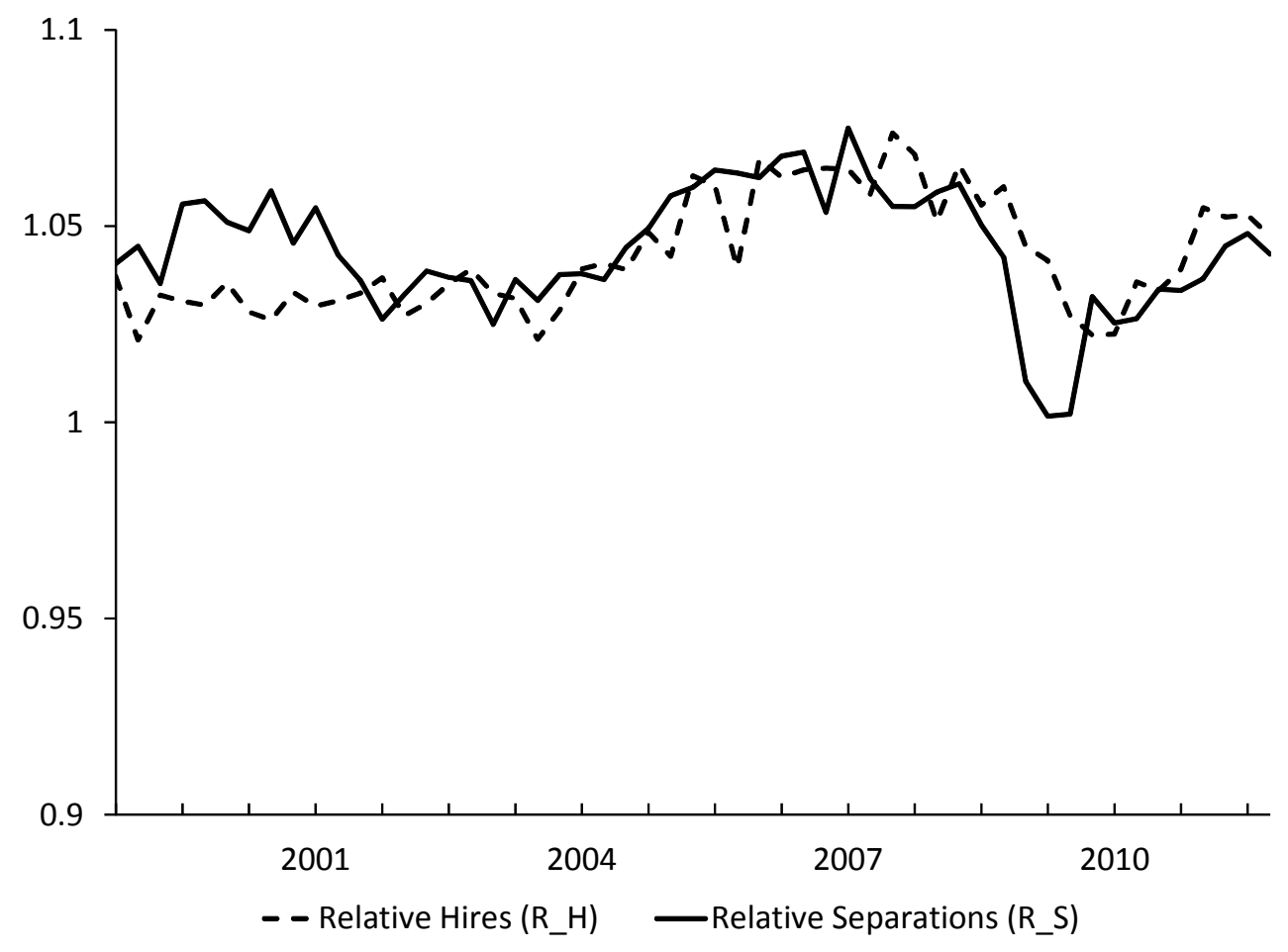

Figure 8: Relative hires, $R_{H}$, and relative separations, $R_{S}$, for young firms 


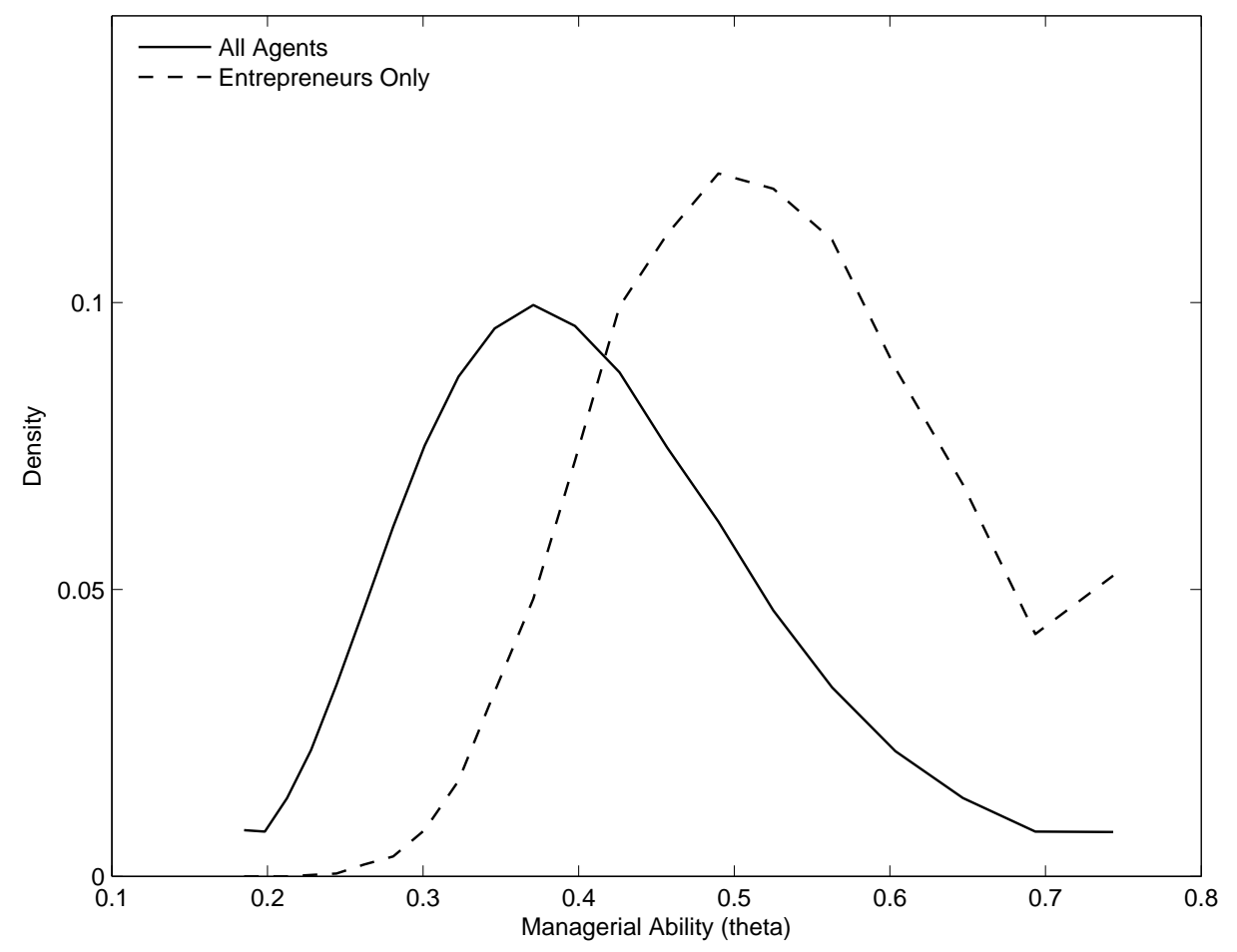

Figure 9: The distribution of entrepreneurial ability, $\theta$

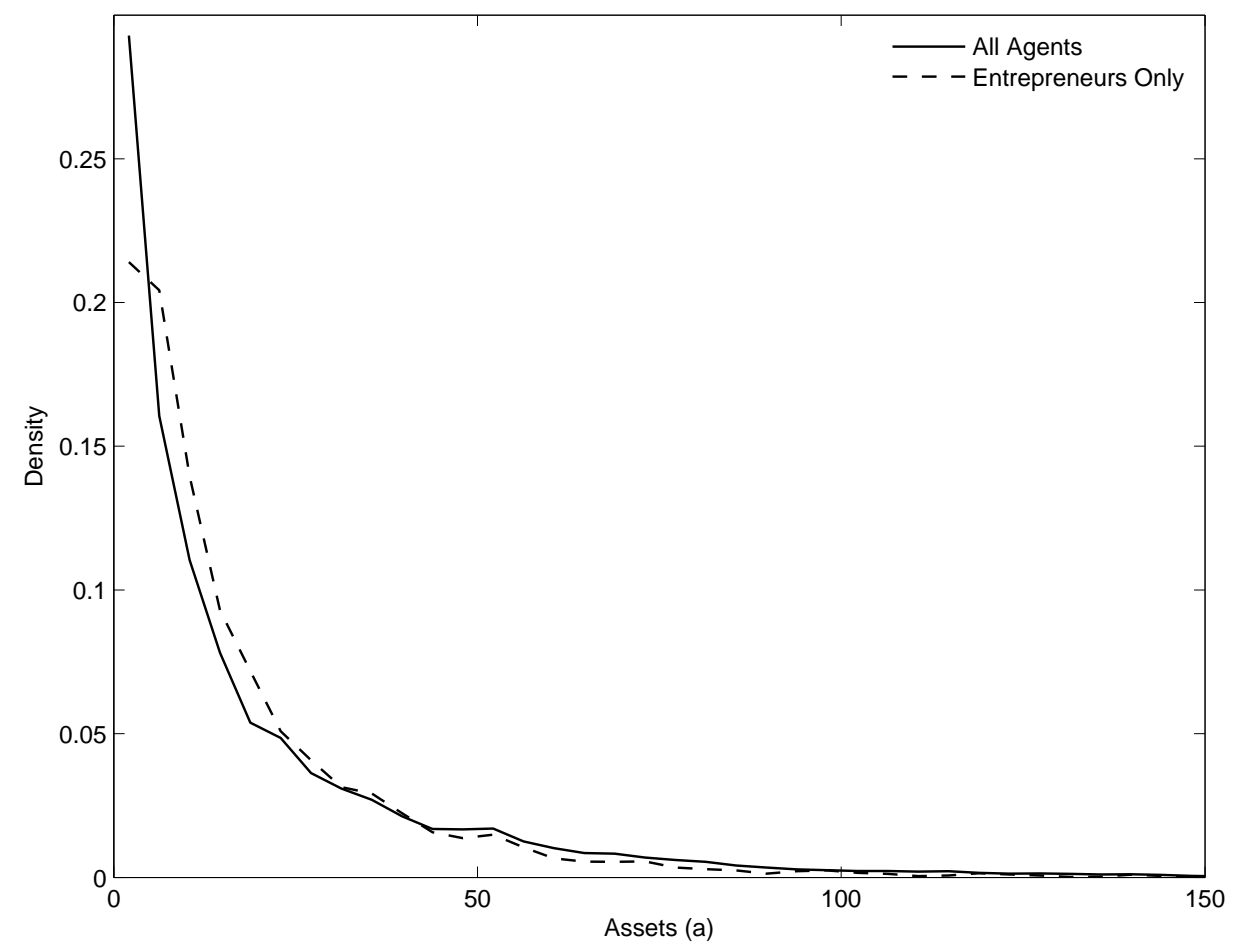

Figure 10: The distribution of assets, $a$, for all agents versus the entrepreneurs 


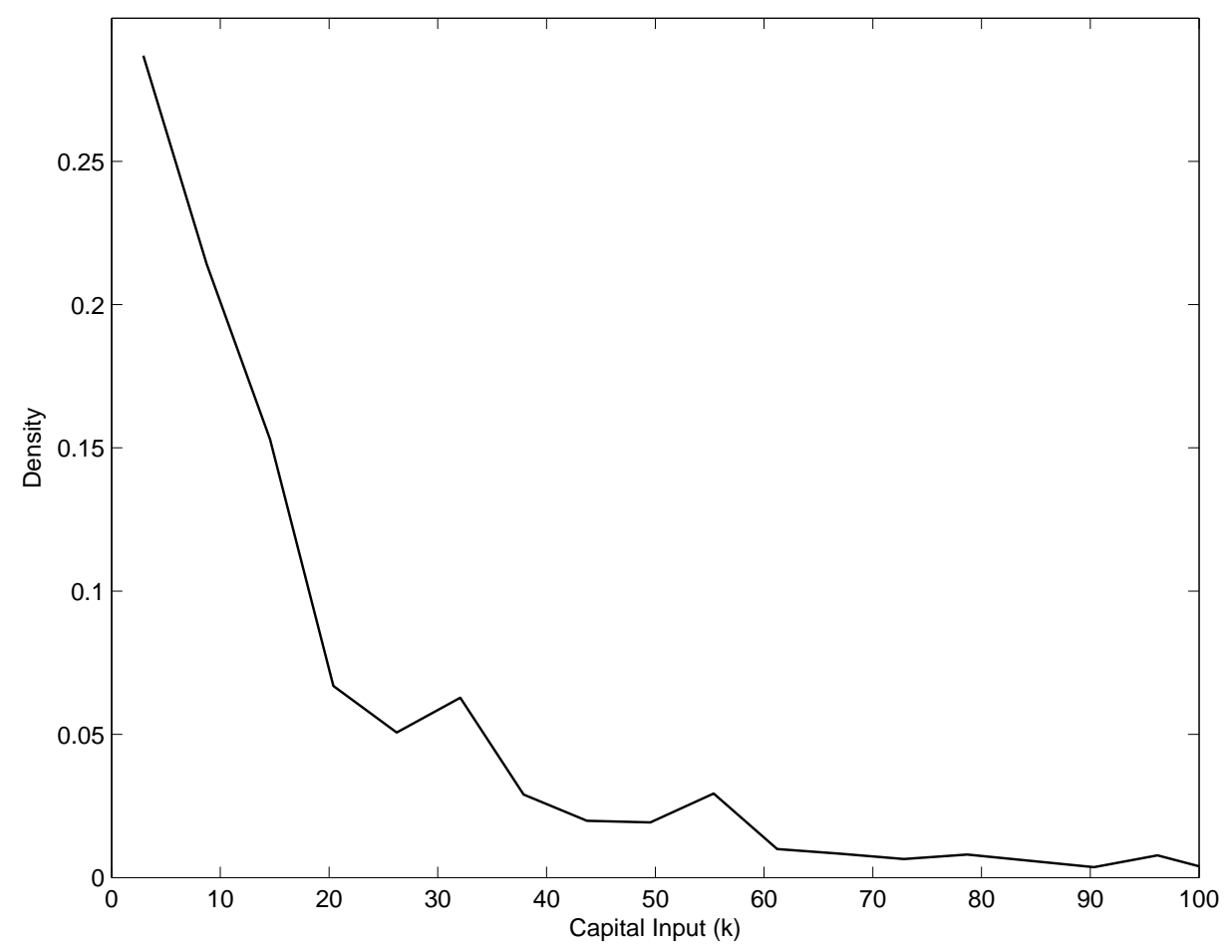

Figure 11: The distribution of capital input, $k$, across entrepreneurs

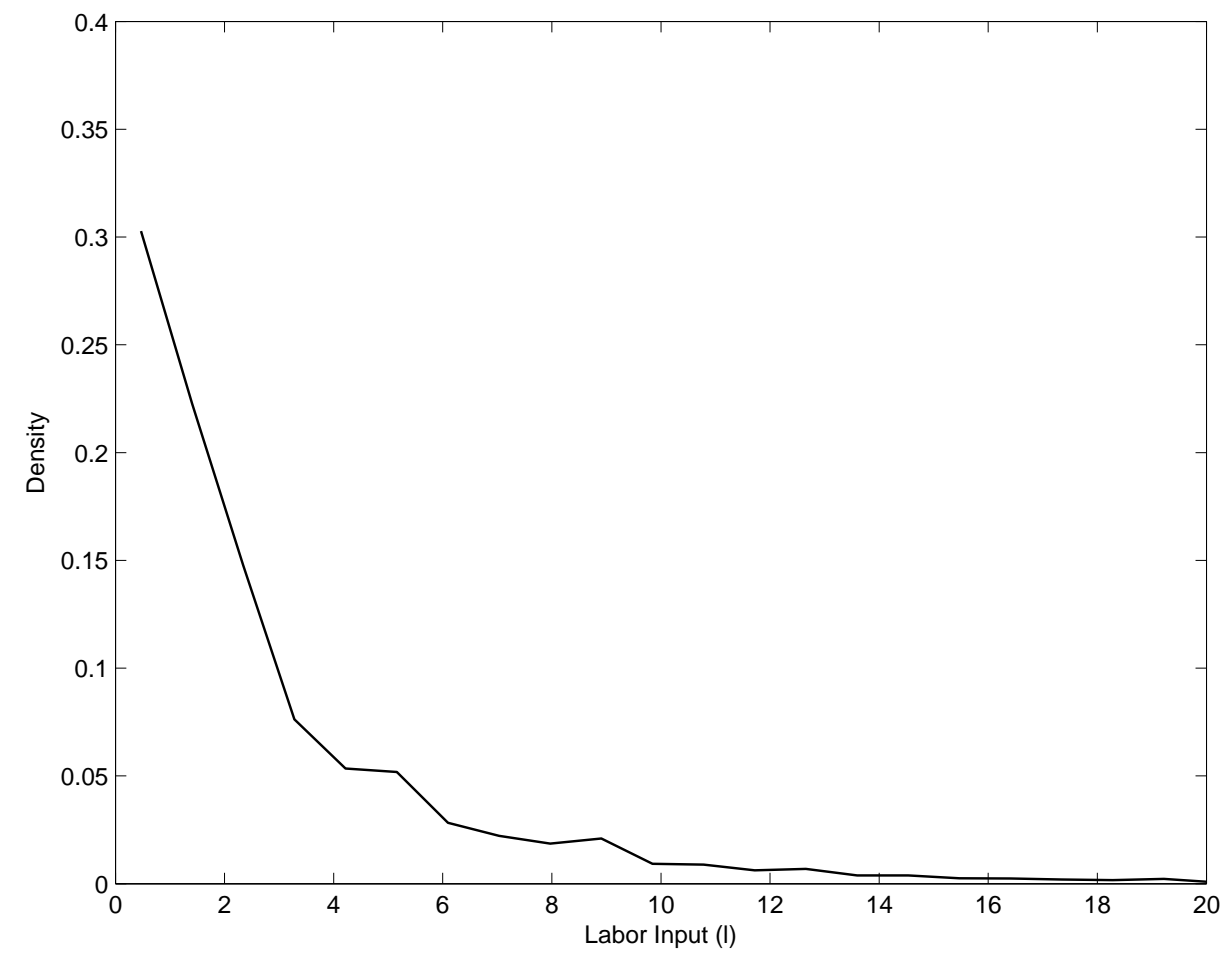

Figure 12: The distribution of labor input, $l$, across entrepreneurs 


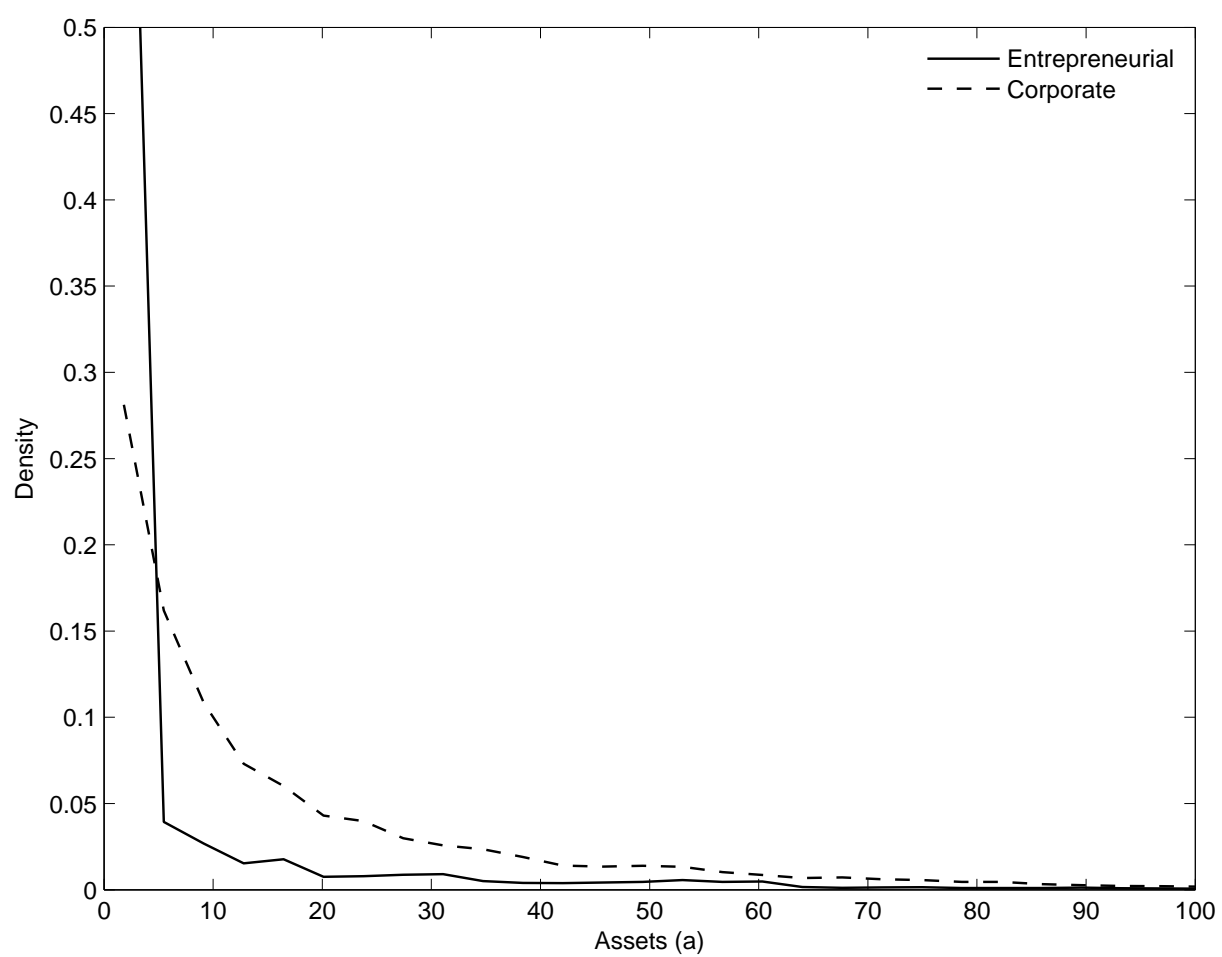

Figure 13: The distribution of assets, $a$, for workers in the entrepreneurial and corporate sectors

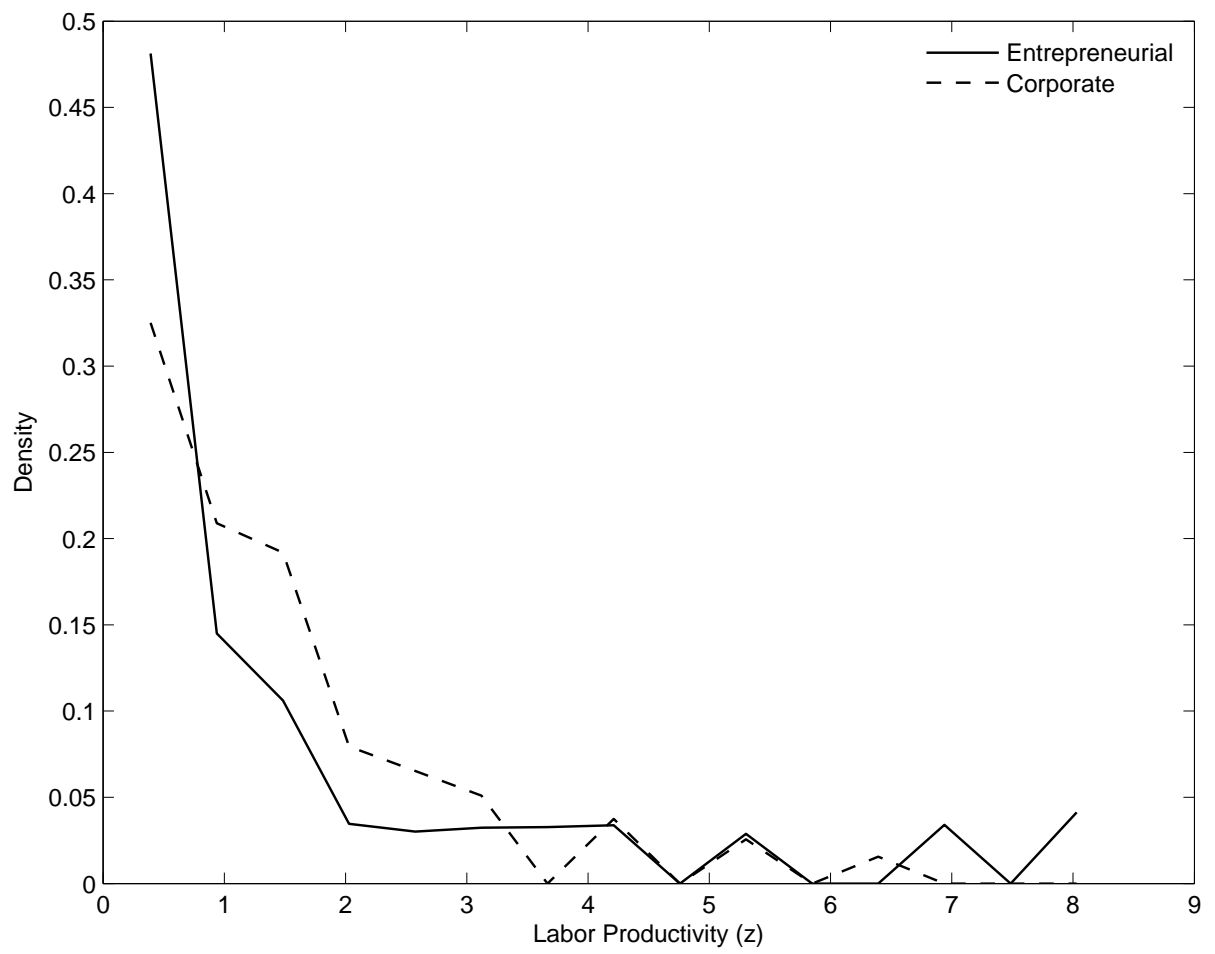

Figure 14: The distribution of productivity, $z$, for workers in the entrepreneurial and corporate sectors 


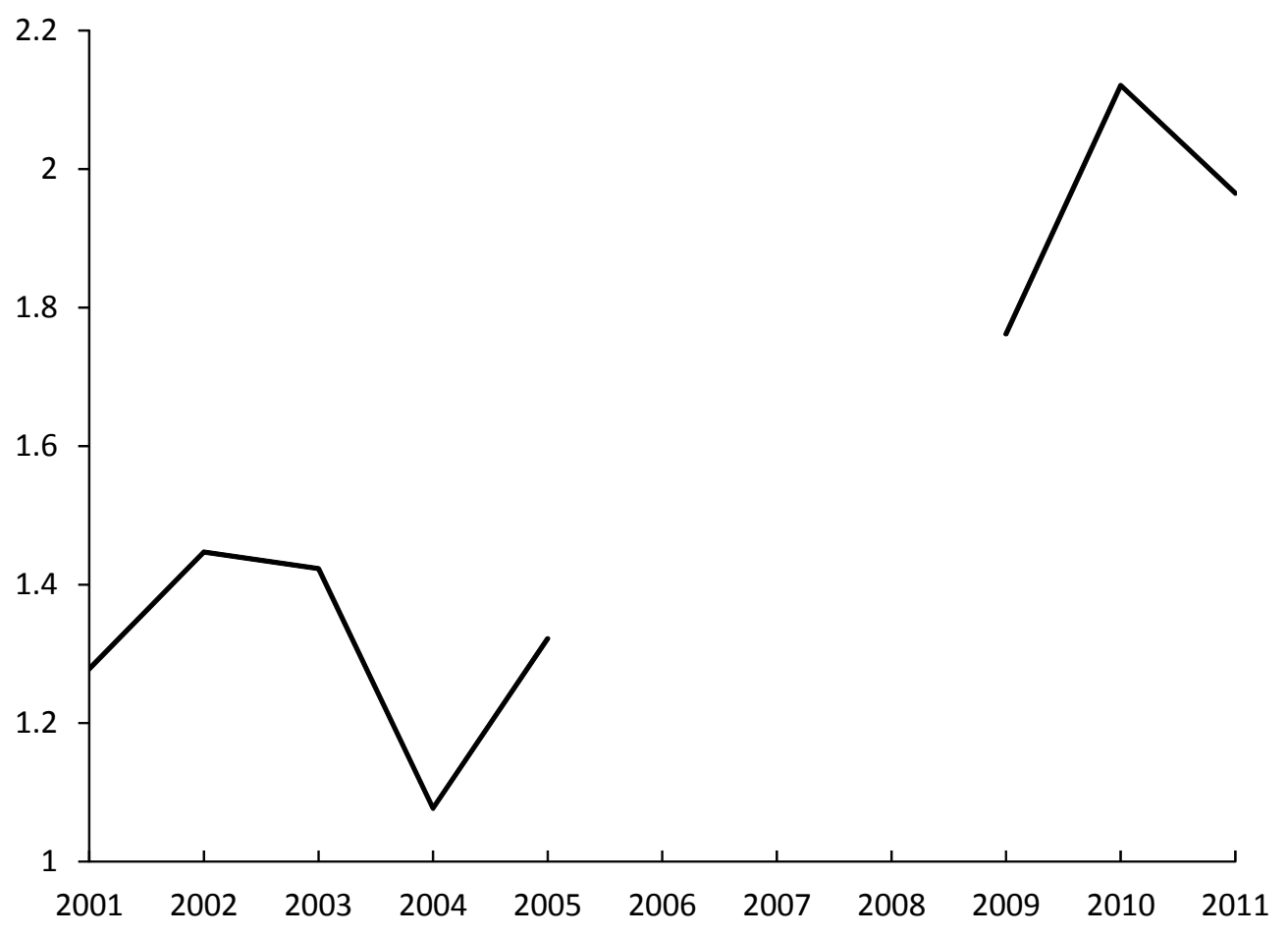

Figure 15: The ratio of mean net worth of workers in mature firms to that in young firms 